\title{
Integrated remote sensing and GIS based spatial modelling through analytical hierarchy process (AHP) for water logging hazard, vulnerability and risk assessment in Keleghai river basin, India
}

\author{
Nityananda Sar $^{1} \cdot$ Soumendu Chatterjee $^{2} \cdot$ Manik Das Adhikari $^{3}$
}

Received: 3 September 2015/Accepted: 9 October 2015/Published online: 23 October 2015

(C) Springer International Publishing Switzerland 2015

\begin{abstract}
Water-logging disaster is a most important environmental as well as socio-economic problem which directly associated with the utilization of soil and land resources in agricultural command areas. Water resource management and conservation is a crucial approach for agricultural development in a basin area. To identify the maximum extent of waterlogged area in a basin during the pre-monsoon, monsoon and post monsoon season necessitated a multidisciplinary approach that integrates the spatial and non spatial attributes on Geographical Information System (GIS) that can be used by the decision makers for implement strategy of the problematic area in term of waterlogged and flood prone region. The main objective of the present investigation is to identify and mapping of the waterlogged disaster areas and it associated risk using an Analytical Hieratical Process and GIS model through ArcGIS model maker in the Keleghai river basin, India. For this purpose, the post monsoon multi-temporal (1976, 1979, 1987, 1990, 1996, 2000, 2005 and 2009) Landsat $^{\mathrm{TM}}$ satellite imagery, topographical maps, ASTER Digital Elevation Model, ground water table and population data have been used to identify the severity level of waterlogged areas and the associated vulnerability level in the basin. We applied digital remote sensing techniques like normalised differences water index, normalised differences vegetation index and normalised differences moisture index to
\end{abstract}

Nityananda Sar

sarnityananda@gmail.com

1 Department of Geography, Kharagpur College, Kharagpur 721301, India

2 Department of Geography, Presidency University, Kolkata, India

3 Department of Geology and Geophysics, IIT Kharagpur, Kharagpur, India identify the water content pixel from the multi-temporal Landsat $^{\mathrm{TM}}$ data. On the other hand, we have considered topographic variation, distance from river and post monsoon groundwater depth as a proxy for waterlogged hazard zoning. In the present study, we applied spatial modelling through Analytic Hierarchy Process (AHP) and GIS to demarcate the hazard and risk level in terms of severe, high, moderate and low. The basic model approach is the conversion of all the thematic layer attributes into a normalised weighted raster as per the water holding capacity through AHP and Multi Criteria Decision Support System. Thereafter, we used combined operation through ArcGIS raster modelling to mapping the severity level of waterlogged hazard area. The assessment of socio-economic impact, we have calculated risk by considering different vulnerability exposures viz. population distribution, settlement density and landuse/landcover. The study demonstrates the integrated remote sensing and GIS based spatial modelling to detect the waterlogged hazard and it associated risk level that occurred due to excessive accumulation of rain and floodwaters. The result depicts the waterlogged hazard zones viz. severe, high, moderate and low and its associated risk levels in the study area which can be helpful for better planning and management of both the drainage system and agriculture activities.

Keywords Command areas - Geographical information system · Ground water table - Hazard · NDMI - NDVI . NDWI · Risk · Vulnerability · Water-logged areas

\section{Introduction}

The rural areas of India are highly vulnerable to the natural and quasi-natural environmental hazard like waterlogging activity. Extreme irrigation with poor drainage 
system increases the water holding capacity of the subsurface litho-stratigraphy. In general, water does not penetrate deeply in the flat topography with extreme irrigation region that raises the groundwater depth as the subsurface soil is fully saturated. Thus, the waterlogged conditions unfavourably affected in the agricultural activities and the rural settlement in the basin area. It is a serious environmental hazard and it is found all over world (Bowonder et al. 1986) viz. China (Quan et al. 2010), Pakistan (Qureshi et al. 2008), Bangladesh (Tutu 2005; Minar et al. 2013), India (Choubey 1998; Chowdary et al. 2008; Sahu 2014), and others. The land degradation process as well as the surface/subsurface soil erosion is highly affected by the waterlogging activity that directly related with the socio-economic and land resources in basin areas (Sahu 2014). India has lost nearly 20,000 and 30,000 ha of irrigated land each and every year owing to water logging due to the barrier of natural drainage, construction of settlements, roads, railways and various structural activities. Periodic monitoring of waterlogged area in the basin through the multi-temporal satellite imagery to help analysing the waterlogged situation and taking appropriate corrective measures. Therefore, an advance integrated remote sensing and GIS based spatial modelling has been used to study the dynamic behaviour of waterlogged areas. Generally, it is initiated in lowlying areas with the absence of high altitudinal variations. Area with low-elevated than its surrounding and the groundwater level is near to the earth surface increase the waterlogged hazard. The seasonal water-logging environment mostly affected local inhabitants as well as it disturbs the surface transport system. Recently, remote sensing and GIS techniques have widely been applied for the purpose of analysis of waterlogged condition with changing space and time. Remote sensing data effectively used to demarcate the small pockets of water-logged areas (Dwivedi 1994). Choubey (1998) identified water-logged hazard zones in Sriram Sagar command area in India by using remote sensing technique. Bhakar (2011) have also capture surface appearance of water-logged areas by satellite imagery. Various methods like normalised differential salinity index, water index, brightness index, wetness index and vegetation indices have been used previously in order to map the areas under risk of waterlogged by considering various remote sensing data (Bhakar 2011). The aims of the present study is to identify and mapping of the water-logged hazard and risk zones through an integrated remote sensing and GIS based spatial modelling using AHP in the Keleghai river basin. Therefore, we have generate different hazard and vulnerability themes viz. NDVI, NDWI, NDMI, groundwater table (GWT), drainage buffer distance (DBD), topographic altitude (TA), demography distribution (DD), settlement density (SD) and landuse/landcover (LULC). For assessed the maximum spatial extent of waterlogged area, we have employed the multi-temporal NDVI, NDWI and NDMI to identify and mapping of water content pixels. On the other hand, several remote sensing and GIS methods are used to identify different LULC classes considering unsupervised, supervised and sub-pixel classification through maximum likelihood method using various multi-spectral images. The water logging hazard map derived by combining the different spatial hazard attributes has been combined with the vulnerability exposure map derived from socio-economic attributes to get risk map of the region. Therefore, a logical attempt has been made for rapid, reliable and accurate assessment of the waterlogged hazard and risk mapping in the agricultural command areas of Keleghai river basin using an integrated remote sensing and GIS techniques which indicate about $35 \%$ of the total area will be severely affected by the waterlogged activity and associated with severe risk index.

\section{Study area}

The study is conducted in the Keleghai river basin in western part of the West Bengal state, India as depicted in Fig. 1 . The study area is covered by $1440 \mathrm{~km}^{2}$ and is known as flood prone area with consisting of low-lying areas (DMP 2002, 2004, 2007, and 2011). Elevation of the study region ranges from between 11 and $102 \mathrm{~m}$ and topographic slope of less than $1.2^{\circ}-23^{\circ}$. The average monsoonal rainfall is observed $1746.6 \mathrm{~mm}$. Thus, the low elevation, poor drainage system, high seasonal rainfall and moderate permeability of soil cause water logging in the study site which is directly affected to the socio-economic development of the basin.

\section{Materials and methods}

The major objective in the present study is to identify the waterlogged area in terms of its hazard, vulnerability and risk zoning in Keleghai river basin using multi-temporal Landsat imageries, groundwater table, drainage networks, topographic variation, demography distribution and socio-economic attributes. Therefore, the major focus of the present investigation are (a) to assess surface water bodies using FFC LISS III, Landsat TM, Google Earth and Topographical data sets, (b) to assess low land waterlogged area based on the contour mapping using ASTER DEM as well as topographic elevation data, (c) to assess the soil moisture content from multi-temporal Landsat imagery through different band ratio technique viz. NDVI, NDWI and NDMI, (d) assessment of 


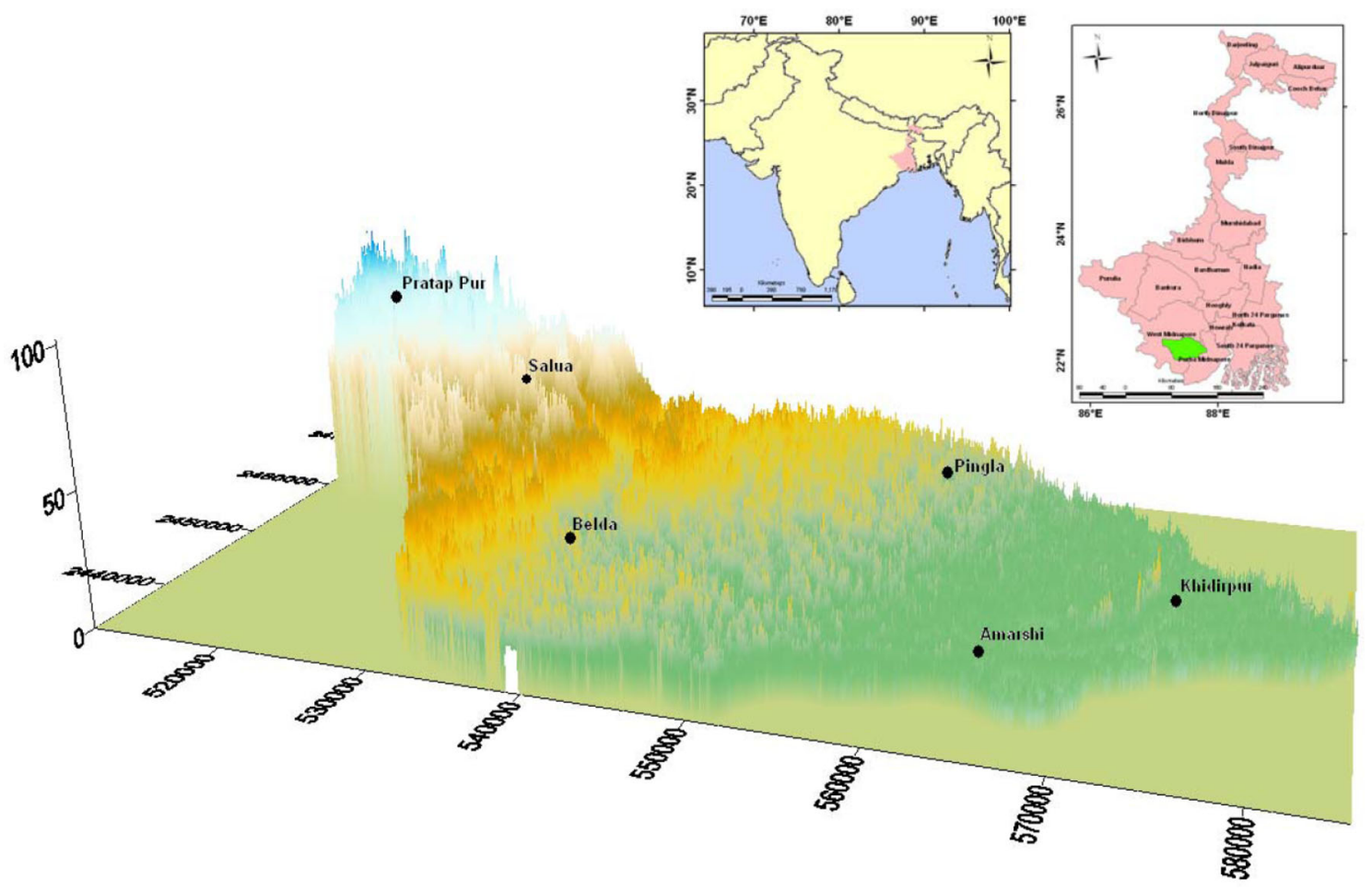

Fig. 1 Location map of the study area

waterlogged areas considering surface drainage network as a proxy of water holding capacity, (e) to established the spatial correlation between the groundwater depth and surface water bodies previously identified from multi-temporal satellite data and Google earth, (f) finally development an integrated spatial modelling through ArcGIS model maker to mapped the waterlogged hazard zones in terms of Severe, High, Moderate and Low considering all the respective water holding thematic layers i.e. NDVI, NDWI, NDMI, ground water table, drainage buffer distance and topographic variation, (g) to assess the vulnerability exposures and (h) to mapped the relative waterlogged risk level using AHP in a GIS environment for the assessment of socio-economic impact in near future in the entire Keleghai Basin.

To achieve the above mention objectives, we have used several spatial and non-spatial data viz. Survey of India (SOI) topographical data sheets of 73N/3, 73N/4, 73N/7, $73 \mathrm{~N} / 8,73 \mathrm{~N} / 11$ and $73 \mathrm{~N} / 12$ with a scale $1: 50,000$, Multitemporal Satellite Imageries (Landsat MSS, TM. ETM), ASTER DEM, groundwater table and rainfall data as illustrated in Table 1.

The integrated remote sensing and GIS techniques are widely used to assess hazard, vulnerability and risk of natural hazards, including water logging (Masuya 2014). Many researchers have used geomorphic, biophysical and socioeconomic attributes to assess water logging hazard and vulnerability around the world (Zhang et al. 2005; Min et al.
2002; Huang et al. 2008; Hailin et al. 2009; Suriya and Mudgal 2012; Kienberger 2012; Wang et al. 2011; Pandey et al. 2010; Meyer et al. 2009; Sinha et al. 2008a, b; Sanyal and Lu 2006; Tingsanchali and Karim 2005). These studies have demonstrated that quantitative analysis of water logging and it associated flood hazards using geospatial techniques help greatly in understanding of complex natural hazards in spatiotemporal contexts (Zhang et al. 2005). As reported by Pandey et al. (2010), Cutter et al. (2009) and Rashed and Weeks (2003), the combined use of geomorphological, social and physical attributes through AHP and multi-criteria evaluation (MCE) to precise assessment of hazard, vulnerability to natural hazards, as they are intrinsically linked. The assessment water logging as well as flood vulnerability using spatial multi-criteria evaluation (MCE) techniques on GIS platform were reported by several researchers (e.g. Pandey et al. 2010; Suriya and Mudgal 2012; Dewan 2013). Willet and Sharda (1991) used AHP to select the optimal flood control projects for the Grand River and Tar Creek in Miami, USA. In India, water logging as well as flood risk analysis using AHP and mapped by GIS has been applied to the Kosi river basin (Sinha et al. 2008a, b). AHP was also used to rank the importance of loss of life and different properties, which is the water logging risk index (Sinha et al. 2008a, b; Huang et al. 2009; Chen and Wang 2014). Hapuarachchi et al. (2011) assess the possible damage and loss due to the water logging hazard by using 
Table 1 List of data and the source of information that used for identification of surface and near surface waterlogged area

\begin{tabular}{|c|c|c|c|}
\hline Data & Source & Type & Time/period \\
\hline Digital elevation model & $\begin{array}{l}\text { http://gdem.ersdac.jspacesystems.or.jp/ } \\
\text { search.jsp }\end{array}$ & Satellite-borne sensor ASTER & $\begin{array}{l}\text { ASTER GDEM V 2.0, 17th October } \\
2011\end{array}$ \\
\hline $\begin{array}{l}\text { Multi-temporal satellite } \\
\text { images }\end{array}$ & http://glovis.usgs.gov/ & Landsat 7 (TM, MSS, ETM) & $\begin{array}{l}11976,1979,1987,1990,1996, \\
2000,2005,2009,2011\end{array}$ \\
\hline LISS III & http://bhuvan.nrsc.gov.in & IRS P6 LISS III & 2012 \\
\hline Rainfall data & $\begin{array}{l}\text { http://www.worldclim.org; http://www. } \\
\text { imd.in }\end{array}$ & Grid data & $1950-2010$ \\
\hline Contour map & Survey of India, Google earth & $\begin{array}{l}\text { Toposheet }(73 \mathrm{~N} / 3 ; 73 \mathrm{~N} / 4 ; \\
73 \mathrm{~N} / 7 ; \\
73 \mathrm{~N} / 8 ; 73 \mathrm{~N} / 11 \text { and } 73 \mathrm{~N} / 12) \\
\text { and Google image }\end{array}$ & 1973, 2011 \\
\hline $\begin{array}{l}\text { Existing surface water } \\
\text { bodies }\end{array}$ & Survey of India, Google earth & Toposheet, Google Earth & 1973,2011 \\
\hline Ground water table & $\begin{array}{l}\text { Centre for Groundwater } \\
\text { Body (CGWB) }\end{array}$ & Ground water depth (m) & 2008-2013 \\
\hline Population data & Census India & Non-spatial data & 2011 \\
\hline
\end{tabular}

GIS. Although many studies have made assessment on waterlogging disaster risk now, it has not developed integrated indexes which can quick access of water logging hazard, vulnerability and risk level as demand by the local government. Thus, in the present study, we developed a holistic methodology for water logging hazard, vulnerability and risk assessment in the Keleghai river basin through AHP and WLC techniques. The major water logging disaster risk forming factors are the hazard, exposure, vulnerability and emergency response. So, the assessment of water logging disaster risk, we have developed a waterlogging disaster risk index (WDRI) on ArcGIS model maker for pre-disaster management and post-disaster mitigation purposes. WDRI involves following steps i.e. (i) to develop a hierarchical structure of the hazard and vulnerability theme through the AHP, (ii) to map the water logging hazard and vulnerability exposures level using MCE through ArcGIS model maker and (iii) to convolve of hazard and vulnerability index to map the overall WDRI.

The spatial MCE technique is the combination of Analytic Hierarchy Process (AHP) and weighted linear combination (WLC) model. AHP and WLC are widely used for spatial modelling to solving the complex problem into small criteria components by integrating different spatial criterion/indicator data layers on GIS environments (Malczewski 2000). It involves the standardization of thematic data layers, assignment of relative weights to the layers using AHP and aggregation of the weighted layers to obtain a single value for each cell or feature (Zhang et al. 2005; Saaty 2000). In the present study, normalization of each thematic attributes has been performed by linear scale transformation technique through a ranking system towards the hazard and risk management: The normalization is performed by using the following formula:

$s=\frac{x-\min }{\max -\min }$

where, $\mathrm{s}$ is the normalized score and min and max represents the minimum rank and maximum rank associated with the thematic attributes, respectively. $\mathrm{X}$ is an indicator rank of that particular attributed.

In the present study, we have used an integrated Remote Sensing and GIS methodology to demarcate the waterlogged hazard and risk index for its socio-economic impact. For obtaining the multi-temporal water contain pixel from Landsat MSS, TM and ETM imagery, we have performed NDVI, NDWI and NDMI through ArcGIS 9.3 and ERDAS Imagine 9.1 software (Tucker 1979; McFeeters 1996; Wilson and Sader 2002). Thereafter, correlation has been prepared, taking the values of NDVI, NDWI, and NDMI to examine and also to understand these three methods are acceptable or not to detect waterlogged area (Chowdary et al. 2008; Choubey 1998). On the other hand, we have considered topographic variation, distance from river and post monsoon groundwater depth as a proxy for waterlogged zoning. Thereafter, we have converted all the thematic layers and its associated theme attribute into a normalised weighted as per the water holding capacity of the respective theme attributes. On the other hand, the vulnerability exposures i.e. LULC, settlement density and population distribution have been integrate using appropriated weight and ranks through MCE. We convolve the hazard and vulnerability index through ArcGIS raster calculator to mapping the WDRI. The complete methodology of the workflow is given in Fig. 2. 


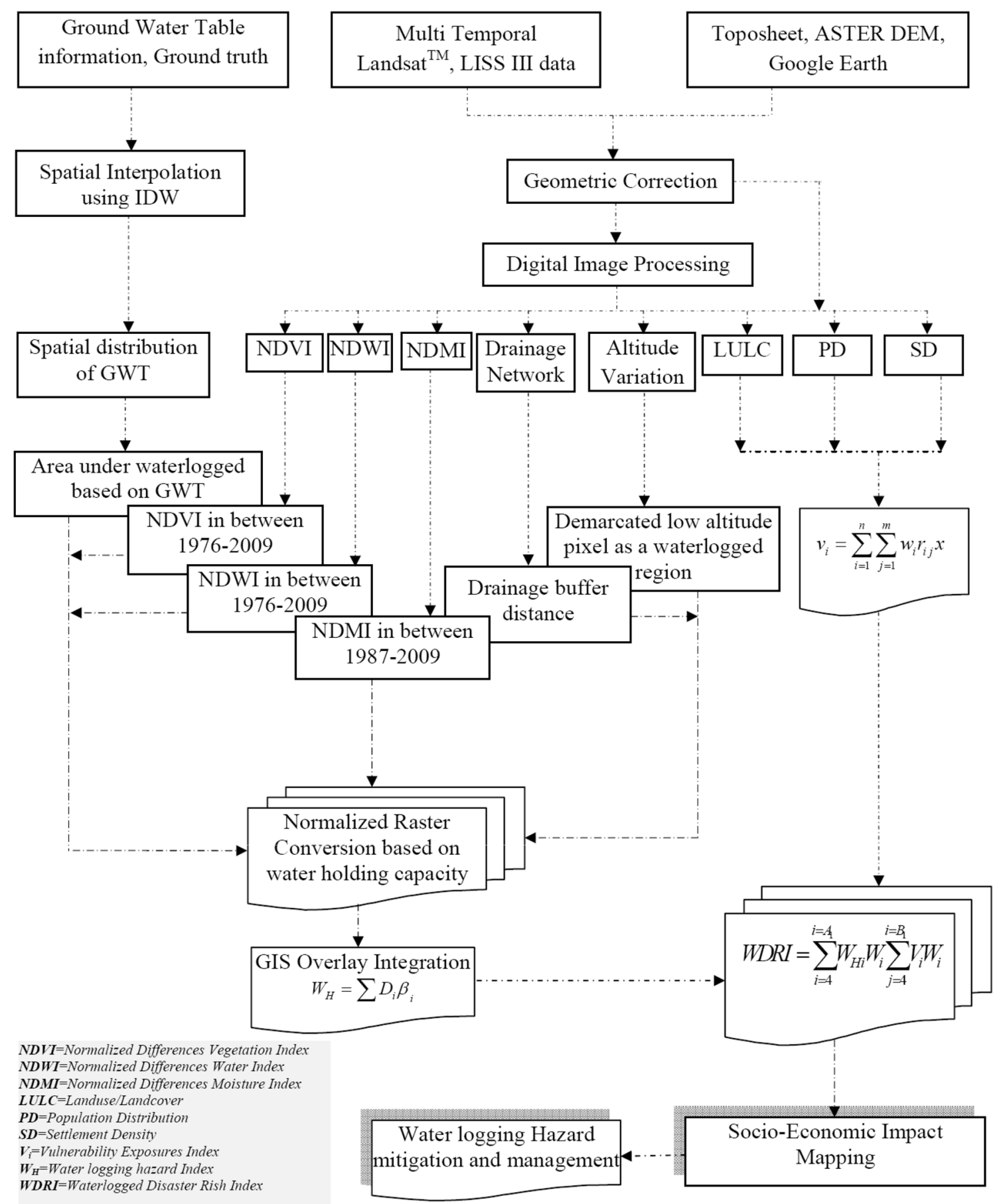

Fig. 2 Framework for water logging hazard, vulnerability and risk mapping for socio-economic impact assessment in Keleghai river basin

\section{Water logging hazard attributes}

\section{Normalized difference vegetation index (NDVI)}

Normalized difference vegetation index is a globally accepted remotely sense index widely used to identification of the vegetation/forest cover and the water bodies over the earth surface (Jackson and Huete 1991; Sahu 2014).
Normalized Difference Vegetation Index computed by following formula i.e. $N D V I=(N I R-R E D) /(N I R+$ RED) (Tucker 1979). It is found that the NDVI value ranges from -1 to +1 , where, +1 represents the dense vegetation. Water typically has an NDVI value of less than zero. In a previous study, Dwivedi and Sreeniwas (2002) considered NDVI value of 0.13 as a threshold value for segregating areas covered with vegetation from water- 
logged areas using Landsat MSS and TM, and IRS-1A LISS-I data. In the present study, we have practiced NDVI technique on multi-temporal Landsat ${ }^{\mathrm{TM}}$ data for identification of water contained pixels. Figure 3 depicted the NDVI map for the period of 1976-2009.

\section{Normalized difference water index (NDWI)}

The normalized difference water index is an alternative remote sensing based index to measure the water content pixel in comparison with NDVI (Sims and Gamon 2003; Gao 1996). The values of the NDWI are arising from -1 to +1 (McFeeters 1996). According to Chowdary et al. (2008) waterlogged areas ranges from 0 to +1 where, +1 indicates the presence of deep water bodies and 0 is for soil moisture. In the resent study, we have used multi-temporal Landsat TM and ETM imagery to generate the NDWI by using the following formula as follows $N D W I=$ $[$ Band $2-$ Band 4$] /[$ Band2 + Band4 $]$ (McFeeters1996). Figure 4 depicted the temporal variation of NDWI value in between the year of 1976-2009.

\section{Normalized difference moisture index (NDMI)}

Crist and Cicone (1984) and Wilson and Sader (2002) explained that the NDMI is the modified version of NDWI which are hypothetically similar to each other for recognition of spatial variation of surface wetness. We have used the Landsat TM and ETM data to analyze the NDMI by using the formula as follows: $N D M I=($ Band $4-$ Band5 $) /$ (Band4 + Band5). In NDMI, the high values indicate the existence of more soil moisture under massive water bodies and lower values of NDMI indicate low soil moisture content as depicted in Fig. 5.

\section{Combined of water content pixel based on multi-temporal NDMI, NDVI and NDWI}

We have produced overall waterlogged area on the basis of existing water content pixels considering multi-temporal NDVI, NDWI and NDMI. Therefore, a correlation has been carry out to understand the relationship between NDVI, NDMI and NDWI of 2009 data shows in Fig. 6ac. The results showed most of the pixel have been concentred with the NDMI value of $0-0.25$ and -0.16 to 0.425 of NDWI value, representing the waterlogged areas of the study site. The association between the NDVI and NDMI showed most of the pixel are concentrated in and between 0 and 0.25 of NDMI value and $0.4-0.6$ of NDVI value. The result of NDVI and NDWI showed a strong positive and linear relation. The water content pixel values of NDWI have been concentred in between 0.160 and 0.425 , whereas for the NDVI index the water content pixels are observed in ranges of -0.01 to -0.68 . Considering all the respective threshold values of NDVI, NDWI and NDMI, we have combined multi-temporal index attributes to an individual raster data base to demarcate the overall water content pixel that indicate the temporal extent of waterlogged area in the Keleghai river basin as depicted in Fig. 7.

Topographic variation in term of contour mapping (AT)

Relief map and slope map of the study region have been generated from the ASTER DEM satellite data. Topographic variation is an important factor for waterlogged situation in a flat terrain (Kaiser et al., 2013). Highest altitude observed in the river basin is $102 \mathrm{~m}$. The lowest altitude i.e. 5-20 m indicated the highest water logged zones in the study site. Zones of highest altitude are affected by low waterlogged situation and area of lowest altitude is highly precious to waterlogged environment as shown in Fig. 8.

\section{Groundwater table (GWT)}

Ground water table is another influencing factor for waterlogged environment (Singh 2011). The surface runoff of the basin is low due to the flat topographic terrain; however, it located in highly precipitation zone. The infiltration rate in the basin area is low due the permanent saturate soil condition as the pore spaces in the soil is filled by the groundwater. In the present study, we collect groundwater table information for the period of 2008-2013 from the Centre for Groundwater Body (CGWB) and subsequently converted into a spatial data base. The spatial interpolation technique i.e. inverse distance weighting (IDW) is frequently used to spatially interpolate of point observation in numerous geosciences applications (e.g. Bonham-Carter 1994; Burrough and McDonnell 1998; Isaaks and Srivastava 1989; ESRI 2003). The IDW interpolator within the geographic information systems (GIS) operates on the assumption that entities in close proximity to one another are more alike than those farther away via an inverse distance-weighted average of the known $\mathrm{z}$ values from a surrounding set of sampled points using the following formula (ESRI 2003):

$\widehat{z}\left(S_{x y}\right)=\sum_{i=1}^{N} \lambda_{i} Z\left(S_{i}\right)$

where, $\widehat{z}\left(S_{x y}\right)$ is the predicted value for location $S_{\mathrm{xy}}, N$ is the number of measured sample points surrounding the prediction location, $\lambda_{i}$ are the weights assigned to each measured point, $Z\left(S_{i}\right)$ is the observed value at the location $S_{\mathrm{i}}$. 

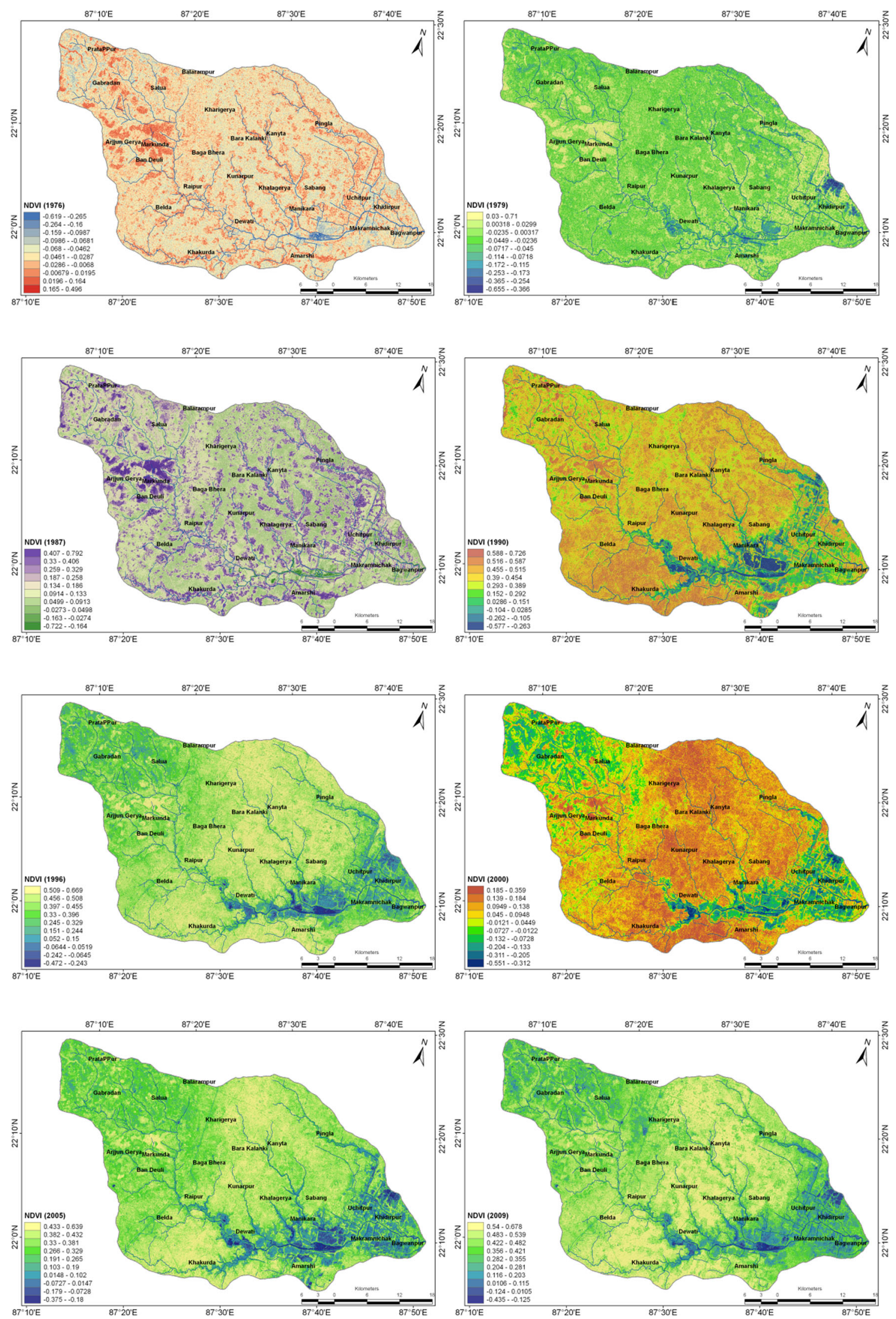

Fig. 3 Normalized difference vegetation index (NDVI) for the period of 1976-2009 of Keleghai river basin 

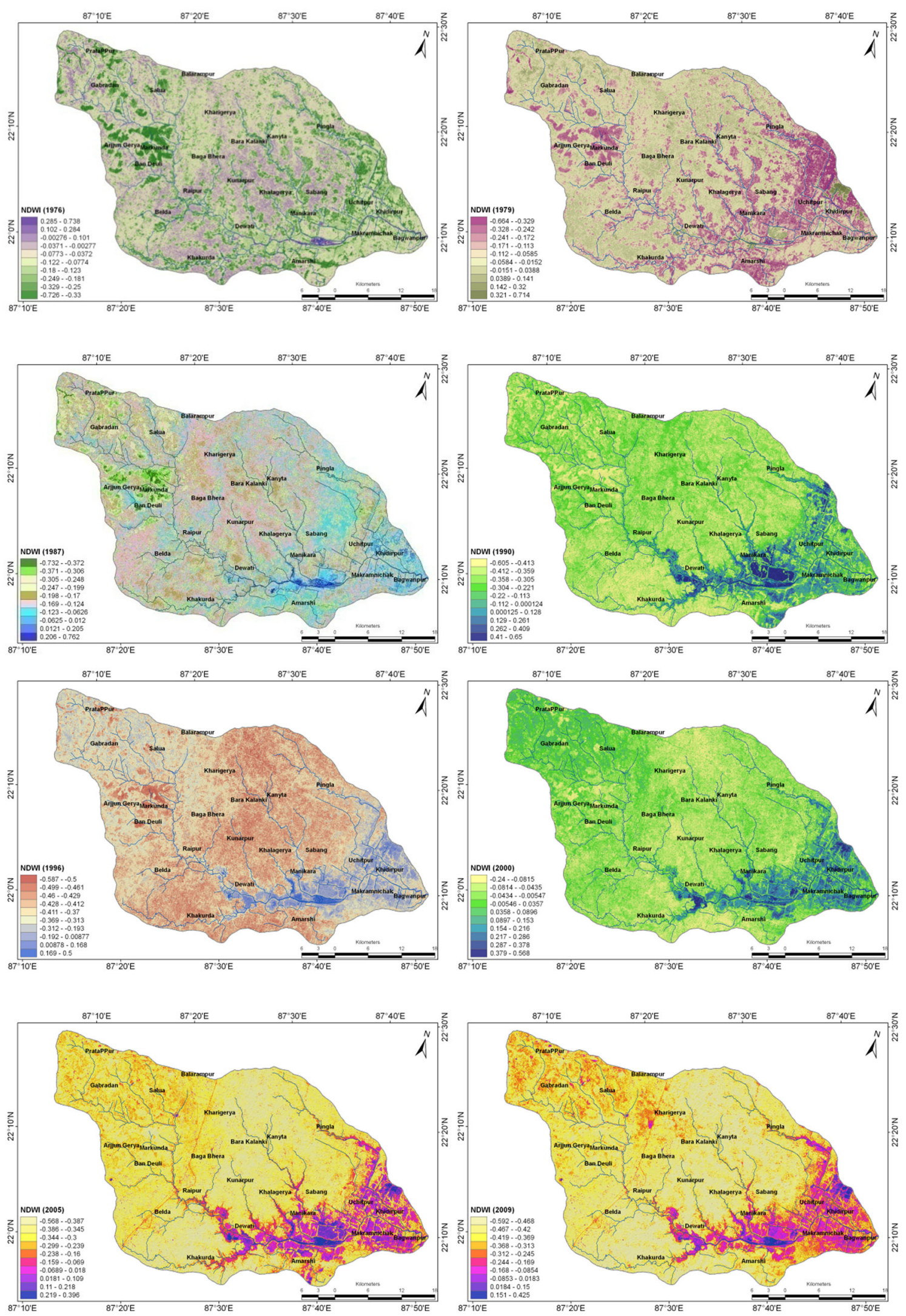

Fig. 4 Normalized difference water index (NDWI) for the period of 1976-2009 of Keleghai river basin 

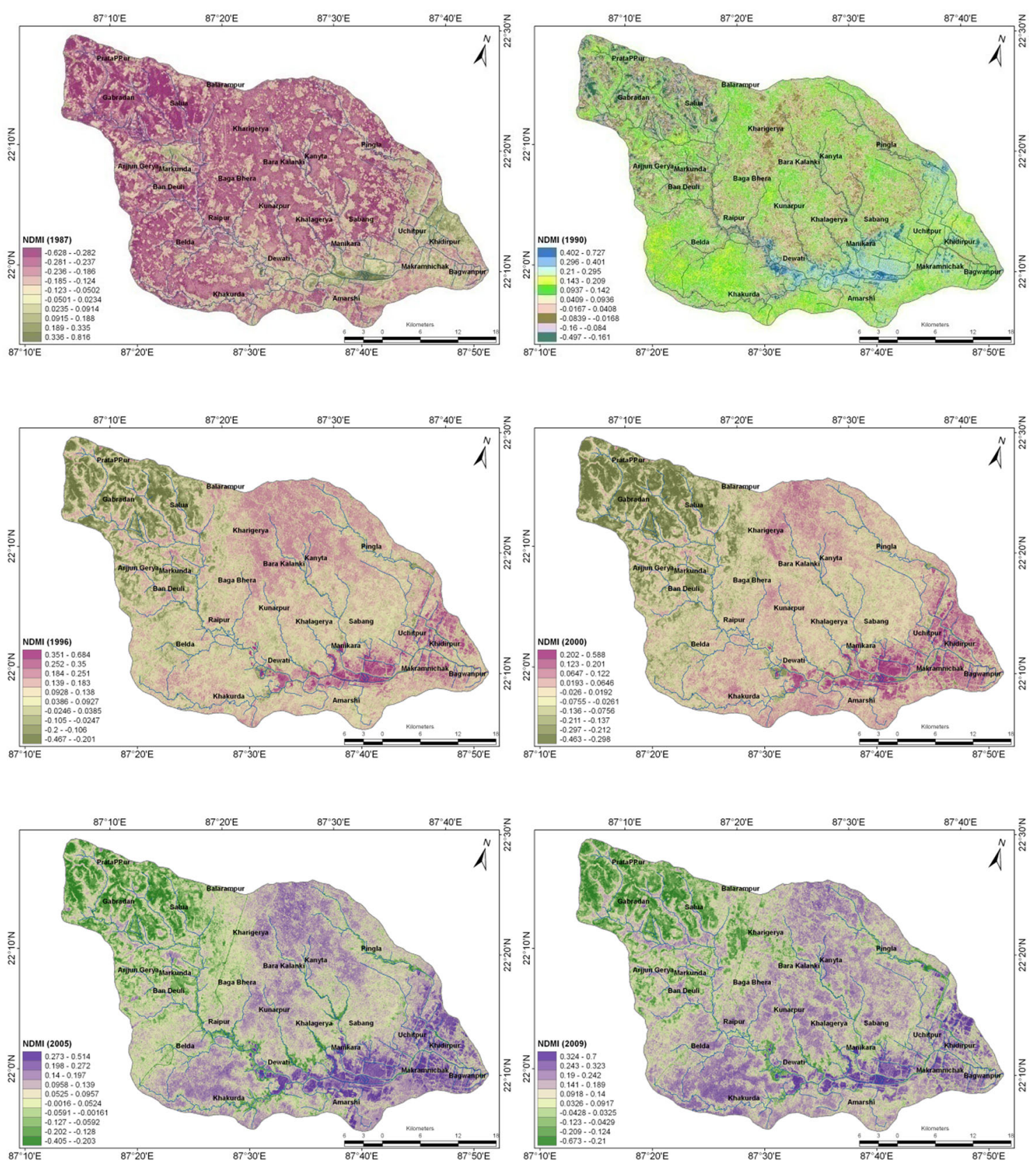

Fig. 5 Normalized difference moisture index (NDMI) for the period of 1987-2009 of Keleghai river basin

The kriging weights have been derived from a simple three-parameter model i.e. semi-variogram that characterizes the spatial dependence in the known data (Meentemeyer and Moody 2000). The weights are derived such that the kriged surface will minimize the error variance, thus providing an unbiased estimate of $\mathrm{z}$ at any un sampled location within the spatial domain (Meentemeyer and Moody 2000). Thus, in the present study, we have used Inverse Distance Weighting (IDW) kriging technique to spatial interpolate the average post monsoon groundwater depth. Figure 9 reveals the highest groundwater depth in the basin is $17.5 \mathrm{~m}$ and lowest is $1.5 \mathrm{~m}$ associated with upper and lower part of the watershed respectively. A zone with highest depth of groundwater table indicates less responsible for waterlogged condition while zones with lowest groundwater depth are highly affected by waterlogged situation as depicted in Fig. 9.

\section{Drainage buffer distance (DBD)}

In the present study, the drainage buffer distance has been used to establish the spatial relation in between the 


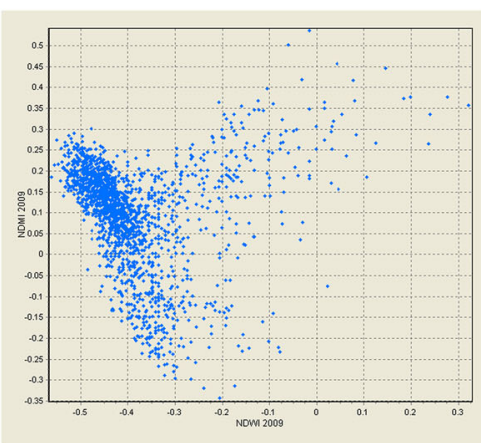

(a)

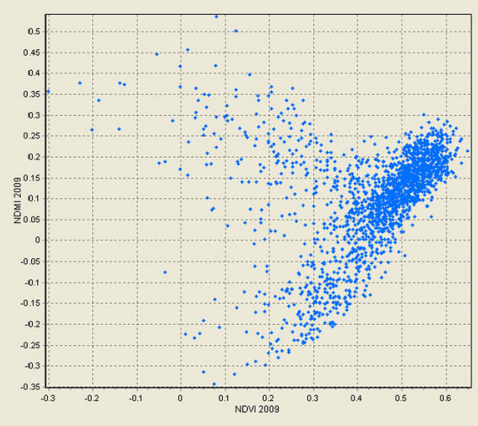

(b)

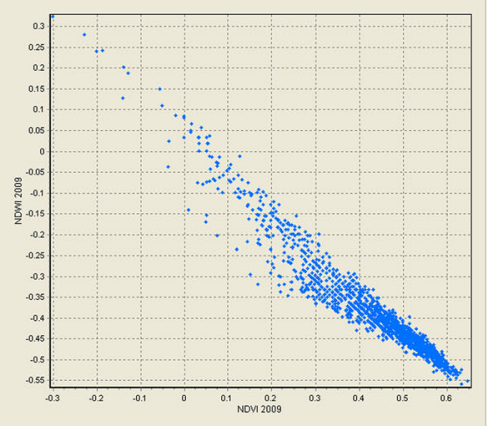

(c)

Fig. 6 Graph showing the relation between NDVI, NDWI and NDMI
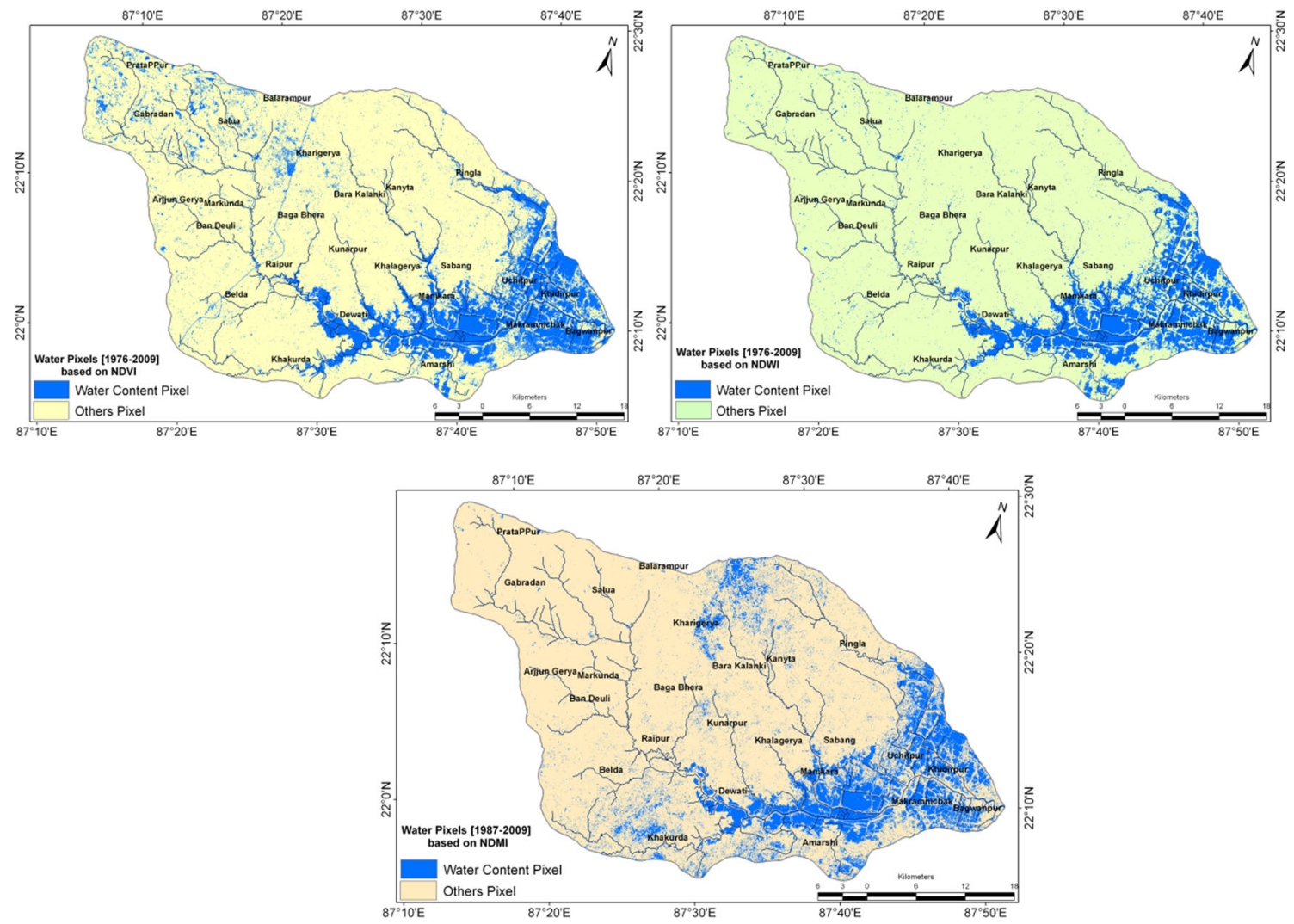

Fig. 7 Waterlogged area identified through combination of all the multi-temporal NDVI, NDWI and NDMI attributes

waterlogged area and the drainage network. For the purpose, we have manually digitized the drainage network from the Survey of India toposheet using ArcGIS software. Thereafter, the distance from river map has been prepared by applying the distance tool in spatial analyst extension of ArcGIS and then classified into ten classes depending on the waterlogged capacity as depicted in Fig. 10. We considered drainage buffer distance as a proxy for waterlogged mapping as it indicated the closer distance from the river is the higher capacity of waterlogging.

\section{Vulnerability and risk exposure attributes}

The concepts of vulnerability and risk have already been analyzed by many researchers (Kates 1985; Blaikie et al. 2005; Downing and Bakker 2000; Pandey et al. 2010; Lu et al. 2010). The vulnerability is the degree of damage to which a socio-economic system is either susceptible or resilient to the impact of natural hazards (Wilhelmi and Wilhite 2002; Pandey et al. 2010). It has been determine by combination of several factors i.e. settlements, 
Fig. 8 Topographic variation in term of contour mapping in the Keleghai river basin depict majority of the low elevation $\sim 5$ to $15 \mathrm{~m}$ in the region
Fig. 9 Spatial distribution of average post-monsoon groundwater table (bgl in $\mathrm{m}$ ) considering data for the period of 2008-2013
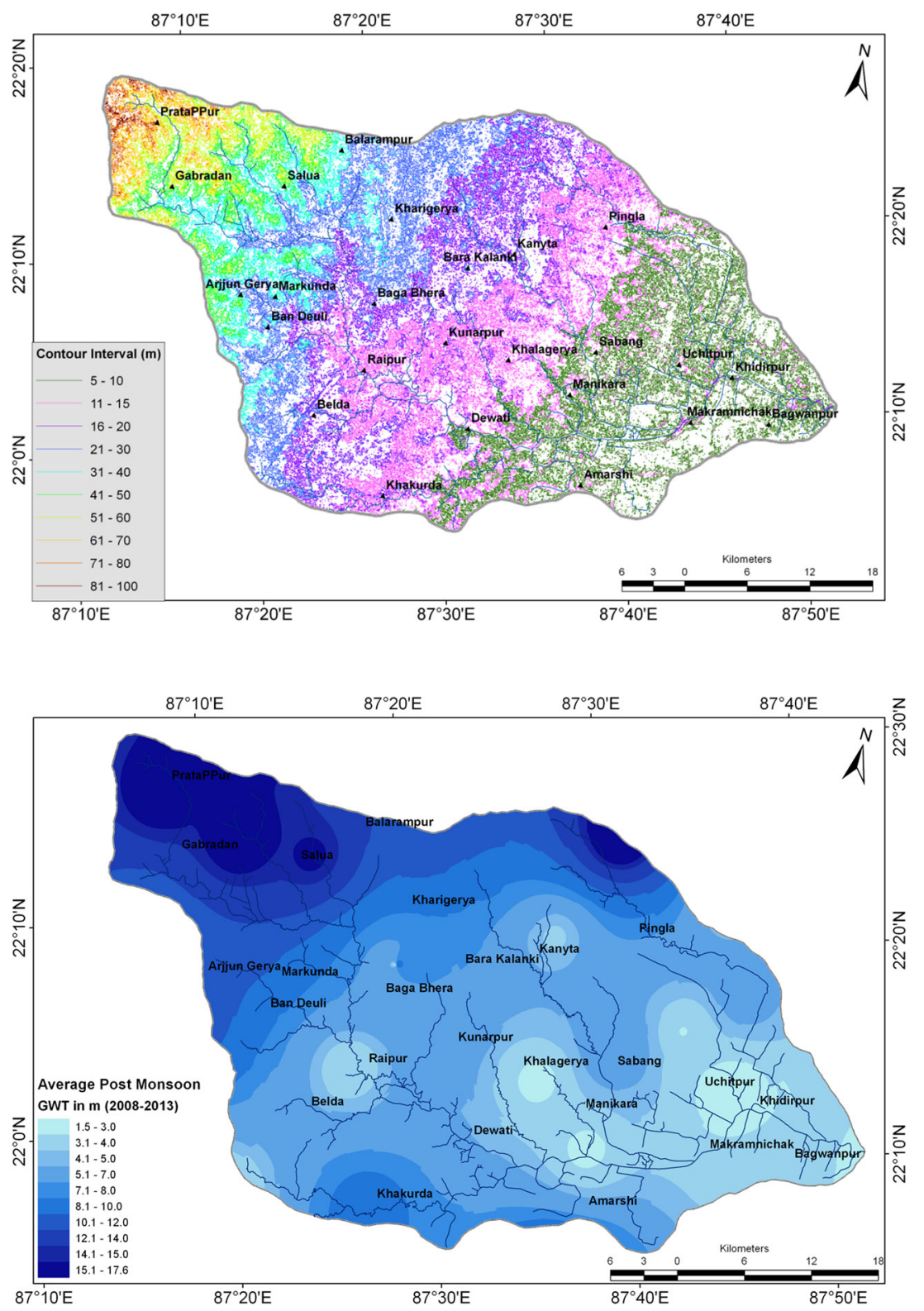

infrastructure, public policy, organizational abilities, social inequalities, gender relations, economic patterns, etc. Waterlogging vulnerability is different for different individuals and nations (Pandey et al. 2010). In developing countries, waterlogging vulnerability constitutes a threat to livelihoods, the ability to maintain productive systems, and economies (Pandey et al. 2010) while in the developed economies, waterlogging poses significant economic risks and costs for individuals, public enterprises, commercial organizations and governments (Downing and Bakker 2000; Pandey et al. 2010). Thus, a holistic waterlogging vulnerability index should take into account ecological, socio-economic and production conditions. Risk is the probability of harmful consequences, or expected losses resulting from interactions between hazards and vulnerable conditions
(Blaikie et al. 2005; Downing and Bakker 2000; Wilhite 2000). Therefore, a conceptual approach to risk assessment can be broken down into a combination of the hazard and vulnerability. Similar to other natural hazard risks, waterlogging risk depends on a combination of the physical nature of waterlogging severity and its interaction with the vulnerability exposures. In the present study, a socioeconomic risk map has been evaluated using demographic distribution, LULC and settlement density of the region with the integration of waterlogging hazard map.

\section{Landuse and landcover (LULC)}

LULC provides information about the predominant urban/ rural landcover and socio-economic attributes that 
Fig. 10 Distance from river in meter as a proxy of waterlogged area in Keleghai river basin
Fig. 11 Landuse/landcover map of Keleghai river basin
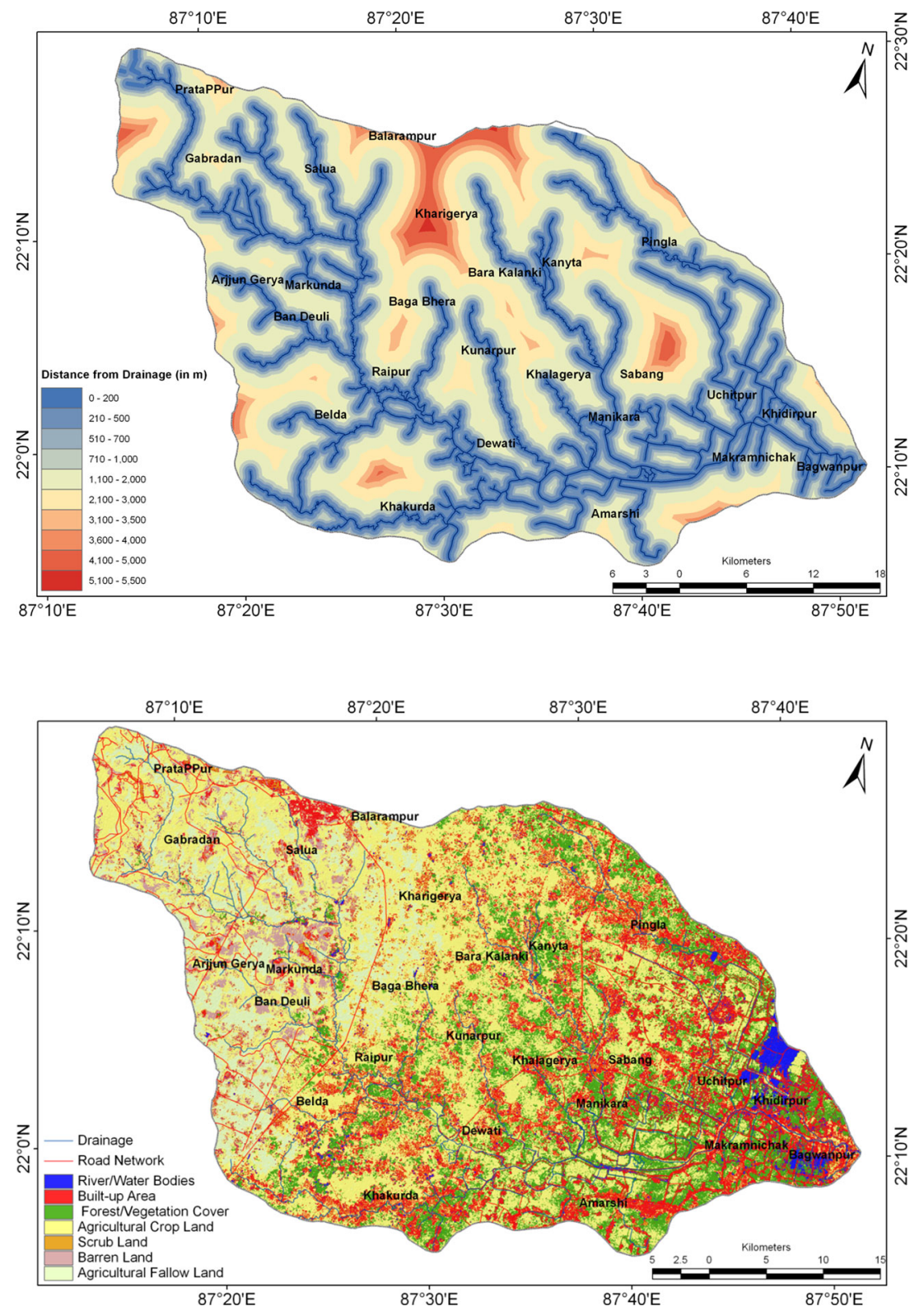

identified by carrying out an object-oriented LULC classification algorithm. In the present study IRS-P6 LISS-III and Landsat ${ }^{\text {TM }}$ data have been classified based on maximum likelihood method using Erdas Imagine software. LULC map of the Keleghai river basin is shown in Fig. 11. The entire study area has been classified into seven major LULC units viz. river/water bodies, forest/vegetation cover, built-up area, scrub land, barren land, agricultural cropland and agricultural fallow land. In the present analysis, we have calculated the user's accuracy, producer's accuracy, overall accuracy and the kappa statistics for the LULC map validation purpose (Story and Congalton 1986; Jensen 1996). The accuracy statistic between the random point driven reference and LISS III/Landsat ${ }^{\mathrm{TM}}$ based classified map is presented in Table 2.

\section{Population distribution (PD)}

On an average, $80 \%$ population of Keleghai river basin is mainly depend on agriculture which will be most affected by waterlogging. Loss of crops due to the waterlogging activities affect cultivator's annual income as their major stock mainly comes from Kharif crops. From a human or economic perspective, the degree of calamity associated with the water logging disaster will depend on the population density of the affected area 
Table 2 Error matrix derived for landuse/landcover mapping in Keleghai river basin

\begin{tabular}{|c|c|c|c|c|c|c|c|c|}
\hline \multicolumn{8}{|l|}{ Random validation data (reference data) } & \multirow[t]{2}{*}{ User's accuracy $(\%)$} \\
\hline Satellite image (LISS-III) based LULC (classified) & RW & $\mathrm{BA}$ & FV & ACL & SL & $\mathrm{BL}$ & AFL & \\
\hline RW & 233 & 4 & 15 & 7 & 5 & 10 & 3 & 84.1 \\
\hline BA & 0 & 264 & 10 & 2 & 25 & 10 & 8 & 82.8 \\
\hline $\mathrm{FV}$ & 10 & 21 & 215 & 16 & 10 & 11 & 22 & 70.5 \\
\hline ACL & 37 & 10 & 13 & 187 & 17 & 14 & 7 & 65.6 \\
\hline SL & 5 & 7 & 9 & 17 & 87 & 21 & 9 & 56.1 \\
\hline $\mathrm{BL}$ & 12 & 3 & 5 & 17 & 23 & 72 & 11 & 50.3 \\
\hline AFL & 13 & 11 & 4 & 3 & 9 & 13 & 181 & 77.4 \\
\hline Total & 310 & 320 & 271 & 249 & 176 & 151 & 241 & \\
\hline Producer's accuracy (\%) & 75.2 & 82.5 & 79.3 & 75.1 & 49.4 & 47.7 & 75.1 & \\
\hline Overall accuracy (\%) & & 72.12 & & & & & & \\
\hline Kappa value & & 0.68 & & & & & & \\
\hline Kappa variance & & 0.000 & & & & & & \\
\hline
\end{tabular}

$R W$ river/water bodies, $B A$ built-up area, $F V$ forest/vegetation, $A C L$ agriculture crop land, $S L$ scrub land, $B L$ barren land, $A F L$ agricultural fallow land

Fig. 12 Population distribution map of Keleghai river basin

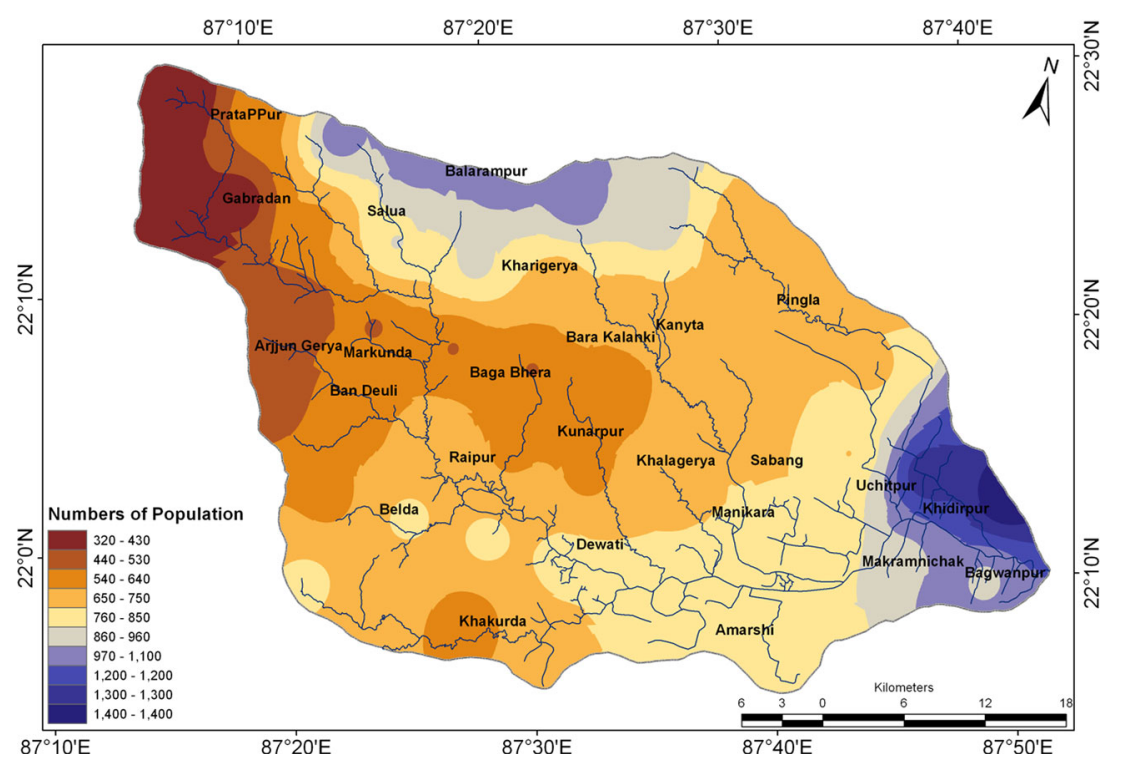

(Pandey et al. 2010). Disasters with similar severity will affect more people if they occur in a highly populated area compared to less populated area. The population distribution map of the Keleghai river basin has been prepare by considering Census 2011 population data as depicted in Fig. 12. Women generally have lower access to all forms of capital and are therefore more vulnerable to disasters than men. It has been observed in widely diverse populations that women are most at risk when disaster unfolds, whether it is a drought (Vaughan 1987) or a cyclone (Ikeda 1995). As waterlogged occur during the monsoon in study region which coincide with the Kharif crop season, a number of men working as agricultural laborers left their native place for need of wages to other agricultural areas in neighboring district and states. Therefore, the woman who left the house is become more vulnerable to waterlogged.

\section{Settlement density $(S D)$}

In the study area, it is observed that the settlement density is high in the high elevated areas to avoid the severity of water-logged hazard. Generally, urban density is defined by the building-to-land ratio or the floor area ratio. However, they are basically estimated by using GIS data which are not always available in the world and usually expensive. 
Fig. 13 Settlement density distribution map of Keleghai river basin

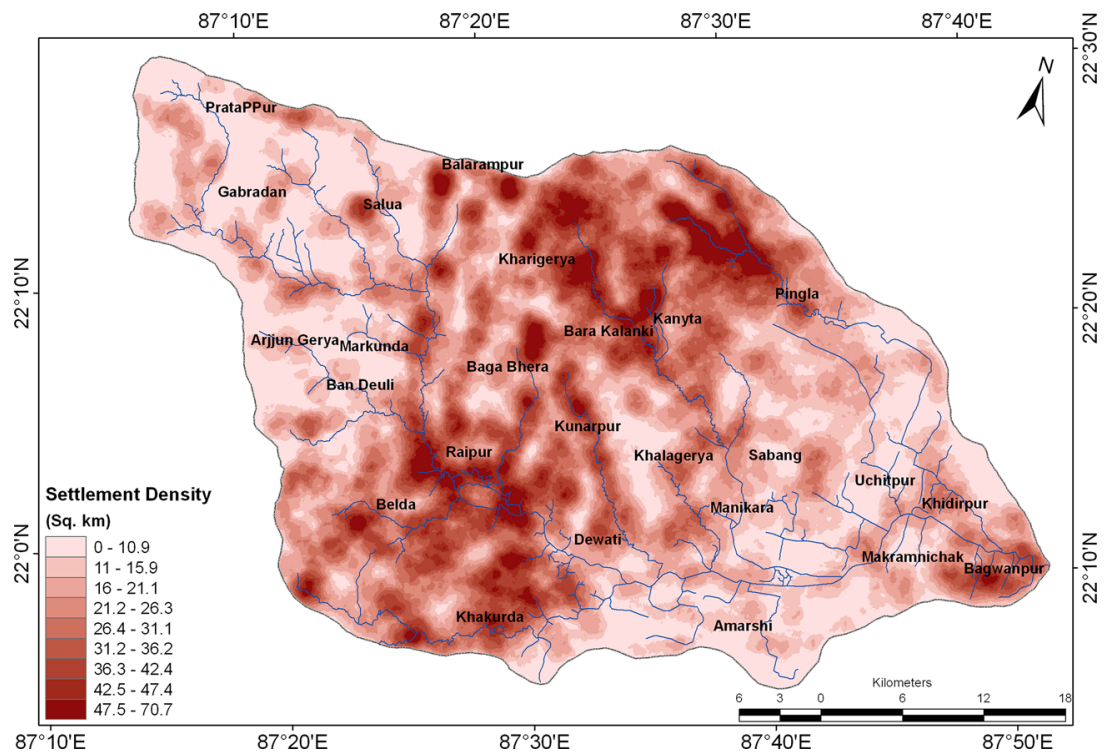

Therefore, using satellite data could be a useful method (Kajimoto and Susaki 2013). Therefore, in the present study, we have use the satellite data (e.g. Landsat TM, Google Earth), survey of toposheet and Open Street map to mapped the settlement density. Figure 13 depicts settlement density map of the Keleghai river basin. Urban density is one of the most important indices for urban monitoring. Urban density indicates not only building density but also indirectly daytime population corresponding to economic power. Sometimes, settlement areas also blocked natural surface water flow and through this way water-logging may be created. In the study area, many houses are observed on the slopes of the embankments since embankments are highlands than the surrounding areas which are highly vulnerable.

\section{GIS based spatial modelling for waterlogged hazard and risk mapping}

To study the risk of waterlogging hazards, it is essential to study the severity, and spatial extent of these hazards as well as the socioeconomic ability of the region to anticipate and cope with the hazards. In the present study, we have used an advance MCE based GIS spatial modelling through ArcGIS model maker considering 'Reclassification', 'Weighted Overlay' and 'Combined' operation for the waterlogging hazard, vulnerability and risk mapping as depicted in Fig. 14. The steps included in Fig. 14 comprises of the primary data used, their manipulation in a GIS environment, multi-criteria decision analysis and model sensitivity analysis. These steps can be categorized as primary and secondary processing stages, with the former being on the processes on data, and the latter being on the algorithmic analysis of the datasets. As depicted in Fig. 14, six different predictor maps have been used as hazard theme represented in the hierarchical structure. Ouma and Tateishi (2014) used Linear Combination Model (LCM) for assessment water logged/flood hazard and vulnerability mapping. Therefore, in the present study we have used LCM for the MCE based hazard and risk assessment through AHP as follows:

$L C=\frac{1}{n} \sum_{i=1}^{n} D_{i} W_{i}$

where, $L C$ is a linear combination; $D_{i}$ is a decision parameter; $W_{i}$ is a AHP weight; $n$ is a numbers of parameters.

In the present study, different water logging hazard thematic layers viz. NDVI, NDWI, NDMI, drainage buffer distance (DBD), groundwater table (GWT) and topographic altitude (TA) have been used for the spatial modelling. Firstly, we have converted all thematic layers into a single georeference system i.e. UTM $45 \mathrm{~N}$ considering equal grid size i.e. $30 \mathrm{~m} \times 30 \mathrm{~m}$. Thereafter, AHP have been used to calculate appropriate weight using a pair-wise comparison matrix as illustrated in Table 3. Based on the water holding capacity, we have assigns rank within each thematic layers attributes as presented in Table 4. The rank has been normalized using the Eq. (1) as discusses earlier. Thereafter, we have covert all the thematic layers into a grid layer using reclassification tools in ArcGIS software. Finally, we development an integrated remote sensing and GIS based spatial model through ArcGIS model maker to mapped the waterlogged hazard level considering all respective normalised raster layers i.e. NDVI, NDWI, NDMI, GWT, DBD and TV. All the normalized grid layers 


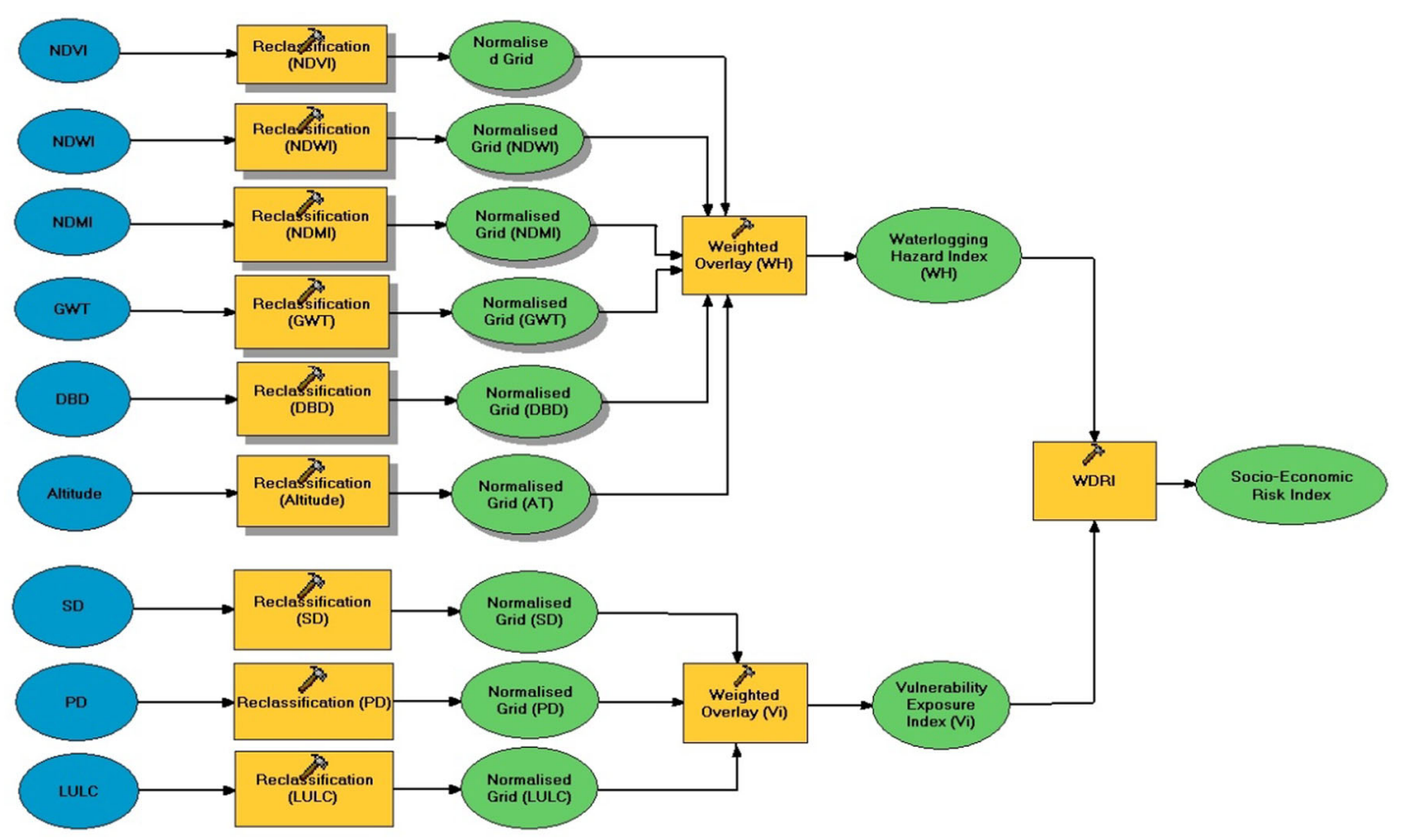

Fig. 14 GIS modeling devolved trough ArcGIS model maker for water logging hazard, vulnerability and risk mapping

Table 3 Pair-wise comparison matrix for different thematic layer considered as a hazard theme for waterlogged hazard mapping

\begin{tabular}{|c|c|c|c|c|c|c|c|}
\hline Themes & NDVI & NDWI & NDMI & GWT & DBD & TV & Weightage \\
\hline Normalized differences vegetation index (NDVI) & 1 & $6 / 5$ & $6 / 4$ & $6 / 3$ & $6 / 2$ & $6 / 1$ & 0.2864 \\
\hline Normalized differences water index (NDWI) & $5 / 6$ & 1 & $5 / 4$ & $5 / 3$ & $5 / 2$ & $5 / 1$ & 0.2381 \\
\hline Normalized differences moisture index (NDMI) & $4 / 6$ & $4 / 5$ & 1 & $4 / 3$ & $4 / 2$ & $4 / 1$ & 0.1905 \\
\hline Ground water table (GWT) & $3 / 6$ & $3 / 5$ & $3 / 4$ & 1 & $3 / 2$ & $3 / 1$ & 0.1429 \\
\hline Drainage buffer distance (DBD) & $2 / 6$ & $2 / 5$ & $2 / 4$ & $2 / 3$ & 1 & $2 / / 1$ & 0.0952 \\
\hline Topographic variation (TV) & $1 / 6$ & $1 / 5$ & $1 / 4$ & $1 / 3$ & $1 / 2$ & $1 / 1$ & 0.0476 \\
\hline
\end{tabular}

have been integrating through 'weighted overlay' tool for ultimate identification of hazard index of waterlogged area by using the modified LCM as follows:

$$
\begin{aligned}
W_{H}= & N D V I_{w} N D V I_{\beta_{i}}+N D W I_{w} N D W I_{\beta_{i}}+N D M I_{w} N D M I_{\beta_{i}} \\
& +G W T_{w} G W T_{\beta_{i}}+D B D_{w} D B D_{\beta_{i}}+A T_{w} A T_{\beta_{i}} / \sum w
\end{aligned}
$$

where, $\beta_{i}$ represent the normalised raster attributes within the theme layers, $w$ is the theme weight and $\mathrm{W}_{\mathrm{H}}$ is the waterlogged hazard index.

The water logging hazard index has been classified into four classes i.e. Severe, High, Moderate and Low as per the geometric mean of $\mathrm{W}_{\mathrm{H}}$ as depicted in Fig. 15. The hazard map shows that the lower part of the Keleghai river basin is severely affected by waterlogging hazard and that expected to flooded during the monsoon season whereas, the upper part of the basin is unlikely affected by the hazard.
The primary aim of risk assessment is to identify riskrelated problems and select appropriate measures to manage risks associated with hazards (Smith 2013). Hence, disaster risk reduction has become an integral part of the entire risk management process and could aid in saving lives and property from catastrophic events (Bendimerd 2008). In developed countries, hazard estimation, mapping vulnerability and risk communication are used to reduce risk and vulnerability in relation to natural hazards (Lu et al. 2010; Maantay et al. 2010; Cutter et al. 2003; Mitchell et al. 1989; Kasperson 1986). In the present study, we have considered LULC, Settlement density and population distribution as a proxy to socio-economic development in the basin. The main socio-economic activities in the basin are the agriculture and fishery that can be directly affected by the waterlogging as the basin is located in flood prone terrain. Thus, it is necessitate 
Table 4 Water logging hazard perspective thematic attributes consider as a proxy for increasing surface and near surface waterlogged area and their ranks and normalized ranks

\begin{tabular}{|c|c|c|c|c|}
\hline Theme & Weighted & Theme attributes & Ranks & Normalised ranks $\left(\beta_{i}\right)$ \\
\hline \multirow[t]{2}{*}{ Normalised difference vegetation index (NDVI) } & \multirow[t]{2}{*}{0.2864} & Combined multi temporal water content pixels & 2 & 1 \\
\hline & & Others pixels & 1 & 0 \\
\hline \multirow[t]{2}{*}{ Normalised difference water index (NDWI) } & \multirow[t]{2}{*}{0.2381} & Combined multi temporal water content pixels & 2 & 1 \\
\hline & & Others pixels & 1 & 0 \\
\hline \multirow[t]{2}{*}{ Normalised difference moisture index (NDMI) } & \multirow[t]{2}{*}{0.1905} & Combined multi temporal water content pixels & 2 & 1 \\
\hline & & Others pixels & 1 & 0 \\
\hline \multirow[t]{9}{*}{ Groundwater table (GWT) (in bgl in $\mathrm{m}$ ) } & \multirow[t]{9}{*}{0.1429} & $1-3$ & 9 & 1 \\
\hline & & $4-5$ & 8 & 0.875 \\
\hline & & $5-7$ & 7 & 0.75 \\
\hline & & $7-8$ & 6 & 0.625 \\
\hline & & $8-10$ & 5 & 0.5 \\
\hline & & $10-12$ & 4 & 0.375 \\
\hline & & $12-14$ & 3 & 0.25 \\
\hline & & $14-15$ & 2 & 0.125 \\
\hline & & $15-17.6$ & 1 & 0 \\
\hline \multirow[t]{10}{*}{ Drainage buffer distance (DBD) (in m) } & \multirow[t]{10}{*}{0.0952} & $0-200$ & 10 & 1 \\
\hline & & $200-500$ & 9 & 0.888889 \\
\hline & & $500-700$ & 8 & 0.777778 \\
\hline & & $700-1000$ & 7 & 0.666667 \\
\hline & & $1000-2000$ & 6 & 0.555556 \\
\hline & & $2000-3000$ & 5 & 0.444444 \\
\hline & & $3000-3500$ & 4 & 0.333333 \\
\hline & & $3500-4000$ & 3 & 0.222222 \\
\hline & & $4000-5000$ & 2 & 0.111111 \\
\hline & & $5000-5500$ & 1 & 0 \\
\hline \multirow[t]{10}{*}{ Topographic variation (AT) (in m) } & \multirow[t]{10}{*}{0.0476} & $5-10$ & 10 & 1 \\
\hline & & $10-15$ & 9 & 0.888889 \\
\hline & & $15-20$ & 8 & 0.777778 \\
\hline & & $20-30$ & 7 & 0.666667 \\
\hline & & $30-40$ & 6 & 0.555556 \\
\hline & & $40-50$ & 5 & 0.444444 \\
\hline & & $50-60$ & 4 & 0.333333 \\
\hline & & $60-70$ & 3 & 0.222222 \\
\hline & & $70-80$ & 2 & 0.111111 \\
\hline & & $80-102$ & 1 & 0 \\
\hline
\end{tabular}

assessing the waterlogged hazard associated vulnerability and risk in the basin.

In the present study, the waterlogging hazard map $\left(\mathrm{W}_{\mathrm{H}}\right)$ has been used along with the socio-economic vulnerability exposures index map to deduce the waterlogging risk pattern at local level using the relation between hazard and vulnerability given by Blaikie et al. (2005), Downing and Bakker (2000) and Wilhite (2000) as:

Water logging Risk $=$ Waterlogged Hazard $\times$ Vulnerability Exposures
To derive the vulnerability exposures index $\left(\mathrm{V}_{\mathrm{I}}\right)$, we have used vulnerability exposures attributes i.e. LULC, SD and PD based on the following equation;

$v_{i}=\sum_{i=1}^{n} \sum_{j=1}^{m} w_{i} r_{i j} x$

where, $w_{i}$ and $r_{i j}$ are the weight for the ith indicator and the rank for the jth class of the ith indicator, respectively where $\mathrm{x}$ represents the value of an indicator.

The intensity of importance for the pair wise comparison has been determined based on literature and exert judgment 
Fig. 15 Demarcated possible areas under waterlogged in Keleghai river basin through spatial combination modelling

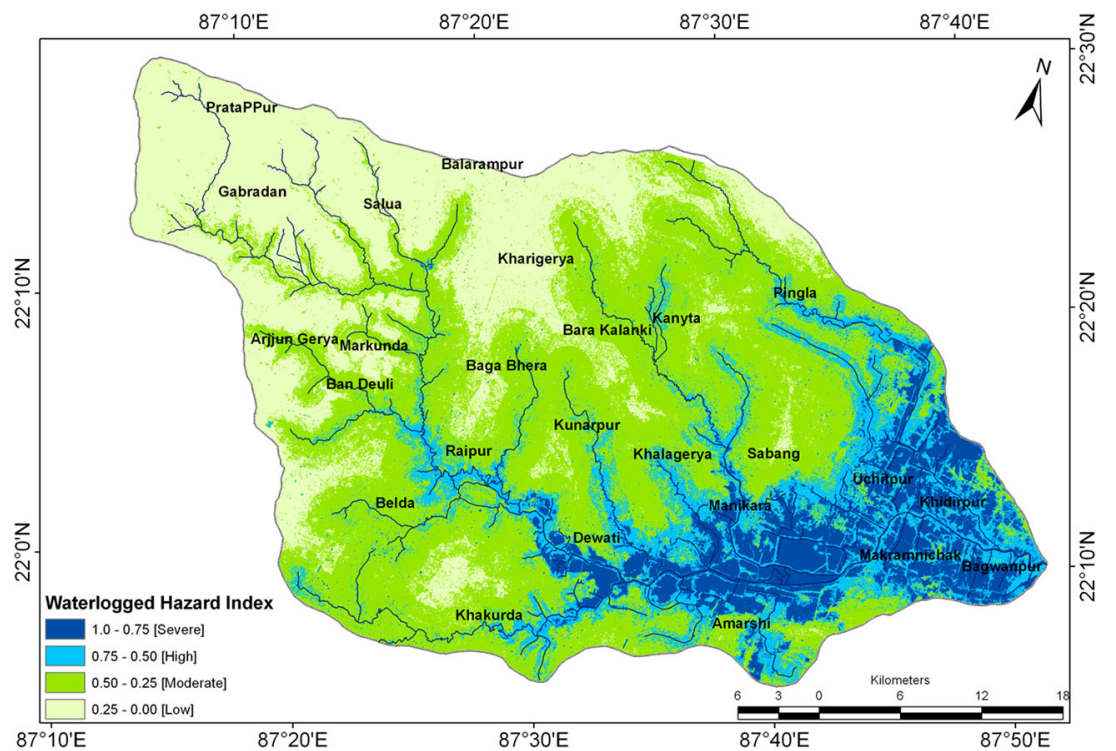

(Hossain 2008; DMB 2007; Islam and Sultana 2006; Rahman et al. 2005a, b) as shown in Table 5. Considering the impact of waterlogged on infrastructure and humans and economic losses in agriculture, the SD have been accorded the highest importance points, followed by PD and LULC.

The total vulnerability index (Dewan 2013) has been calculated by performing WLC with equal weights on the indices derived from the hazard and vulnerability analyses described above. As in the estimation of the total vulnerability index, the cell-based water logging hazard map has been integrated with the total vulnerability index. The final risk index has been calculated with the following equation:

$W D R I=\sum_{i=4}^{i=A_{1}} W_{H_{i}} W_{i} \sum_{j=4}^{i=B_{1}} V_{i} W_{i}$

where, WDRI is the water logging disaster risk index, $W_{H_{i}}$ represent the local level water logging hazard index; $V_{i}$ represents the local level socio-economic vulnerability index. Due to the product relationship, if there is no chance for the hazard or there is no socio-economic vulnerability, the water logging risk for that location is zero. To generate criterion values for each evaluation unit, each factor has been weighted according to the estimated significance towards risk. The inverse ranking was applied to some of these factors, with ranks of 0 being the least important and 1 is the most important factor. The resulting risk index has been categorized into four class i.e. low, moderate, high and severe using the natural breaks algorithm as depicted in Fig. 16. The risk map prepared based on said model indicates severe $(33 \%)$ and high $(17 \%)$ waterlogging risk in the mostly lower part of the basin.

\section{Results and discussions}

Water logging hazard and risk is a major global issue that directly affected to the economic development in a cultivated Country. In India, extensive region were water-logged within the various states due to the poor irrigation and maintenance of surface drains in the twentieth century (Ritzema et al. 2008). The southern part of West Bengal as well as the present investigate site remained waterlogged for a long time due to accumulated of floodwater (Mukherjee 1985). From the multi-temporal Landsat ${ }^{\mathrm{TM}}$ and Google earth imageries, it is observed that the water-logging is frequently found in the present study region. It is also observed that each and every year waterlogged situation initiated during the monsoon and early post monsoon season (Sahu 2014). It is drastically change during the early monsoon season as the average monsoonal rainfall in the basin is $1746.6 \mathrm{~mm}$ (Malik et al. 2002). Due to the uncertainty of monsoonal rainfall, the waterlogged condition is found to be temporal variable, as early if the rain is coming in the beginning of monsoon season and vice versa. It is also found that the most of the water-logged area are associated with the agricultural lands in the basin. It is observed that the waterlogged zones are primarily located on the low-lands than their surroundings. As discussed earlier, the altitude of the basin ranges from almost $1-102 \mathrm{~m}$ with flat topographic slope within $1.2^{\circ}-23^{\circ}$. The topographic undulation indicates the lower part of the basin is more vulnerable to waterlogged condition.

The waterlogging prone area have also identified from the multi-temporal Landsat ${ }^{\mathrm{TM}}$ imageries for the period of 1976-2009. The water contain pixels have been extracted from multi-temporal NDVI, NDWI and NDMI and 
Table 5 Water logging vulnerability perspective thematic attributes with weight, ranks and normalized ranking of theme attributes

\begin{tabular}{|c|c|c|c|c|}
\hline Theme & Weighted & Theme attributes & Ranks & Normalised ranks $\left(\beta_{i}\right)$ \\
\hline \multirow[t]{9}{*}{ Settlement density (SD) (sq.km) } & \multirow[t]{9}{*}{0.50} & $0.0-10.9$ & 1 & 0 \\
\hline & & $11.0-15.9$ & 2 & 0.125 \\
\hline & & $16.0-21.1$ & 3 & 0.25 \\
\hline & & $21.2-26.3$ & 4 & 0.375 \\
\hline & & $26.4-31.1$ & 5 & 0.5 \\
\hline & & $31.2-36.2$ & 6 & 0.625 \\
\hline & & $36.3-42.4$ & 7 & 0.75 \\
\hline & & $42.5-47.4$ & 8 & 0.875 \\
\hline & & $47.5-70.7$ & 9 & 1 \\
\hline \multirow[t]{10}{*}{ Population distribution (PD) } & \multirow[t]{10}{*}{0.33} & $320-430$ & 1 & 0 \\
\hline & & $431-530$ & 2 & 0.111111 \\
\hline & & $531-640$ & 3 & 0.222222 \\
\hline & & $641-750$ & 4 & 0.333333 \\
\hline & & $751-850$ & 5 & 0.444444 \\
\hline & & $851-960$ & 6 & 0.555556 \\
\hline & & $961-1100$ & 7 & 0.666667 \\
\hline & & $1101-1200$ & 8 & 0.777778 \\
\hline & & $1201-1300$ & 9 & 0.888889 \\
\hline & & $1301-1400$ & 10 & 1 \\
\hline \multirow[t]{7}{*}{ Landuse/landcover (LULC) } & \multirow[t]{7}{*}{0.17} & Scrub land & 1 & 0 \\
\hline & & Barren land & 2 & 0.166667 \\
\hline & & River/water bodies & 3 & 0.333333 \\
\hline & & Forest/vegetation cover & 4 & 0.5 \\
\hline & & Agricultural fallow land & 5 & 0.666667 \\
\hline & & Agricultural cropland & 6 & 0.833333 \\
\hline & & Built-up area & 9 & 1 \\
\hline
\end{tabular}

Fig. 16 The vulnerability map of the Keleghai river basin considering built-up and agricultural activity in the region

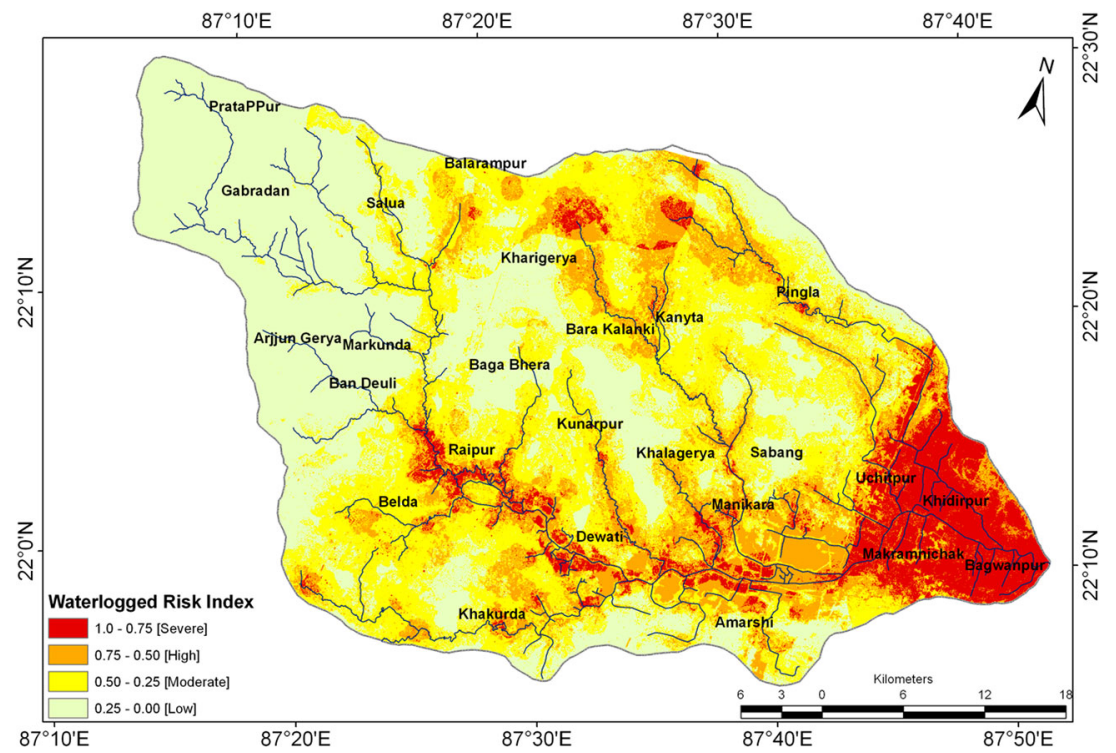

thereafter we have performed overlay operation through ArcGIS spatial analysis tool to obtain the ultimate waterlogged area of individual index in the basin. It is indicating the maximum spatial extent of water logging areas that mostly cover in the eastern part of the basin. The analysis showed waterlogged area portrayed mostly in the lower part of the study site. On the other hand, the water table depth varies from 2 to $4 \mathrm{~m}$ in the lower part of the 
Basin indicating high soil moisture as well as low water penetrate soil are associated in the region. The upper part of the basin associated with low water table depth i.e. $10-17 \mathrm{~m}$. There is a relation between altitude and water logged area with the respect to mean annual rainfall i.e. the upper part of the basin associated with highest altitude i.e. $102 \mathrm{~m}$ that indicate the lowest groundwater table depth viz. 10-17 $\mathrm{m}$ also observed the minimal water logged zones and it vice versa. It is also observed from the multi-temporal Landsat ${ }^{\mathrm{TM}}$ data and Google Earth imagery that the waterlogged area associated with close proximity to the drainage networks. Thus, we have prepared the drainage buffer distance theme as the close proximity is the higher vulnerability and it vice versa. Finally, all the theme have been combine through ArcGIS spatial analysis tool as discussed in "Landuse and landcover (LULC)" reveals the water-logged hazard zone in terms of low, moderate, high and severe. The severe zone is found about $350 \mathrm{~km}^{2}$ which can be occurred during the monsoon and early post-monsoon season in the Keleghai river basin as depicted in Fig. 15. The water-logged areas have been found to be distributed along the mostly lower part of the river basin. However, this type of environmental hazard in the lower basin is mostly seasonal in nature. Therefore, in the monsoon and post monsoon season, exceptional waterlogged condition may occur as the soils will highly wet and moist during this season that can create extreme flood condition in the lower part of the basin. This waterlogged and extreme flood condition will directly impact on the socioeconomic activity in the region. Figure 16 depicted the socio-economic risk index in the Keleghai river basin. In the present study, we have used LULC, PD and SD as major socio-economic units for vulnerability mapping. The vulnerability map can be used for the decision making and sustainable development purpose as the economic activity in the region are mainly depend on the paddy cultivation and fishing that can be directly affected by the waterlogging and the extreme flooding condition. It is observed that the some settlements of low laying areas in the lower part of the basin are significantly affected by the waterlogged as well as flood condition each and every year in the time of monsoon season that can be improved by using the Figs. 15 and 16. As the waterlogged is a natural or quasi natural hazard, therefore, this study can be used for the pre disaster management and post disaster mitigation purposes.

\section{Conclusion}

The present study related to determine the water logging hazard, vulnerability and risk in the Keleghai river basin by combined raster modelling using an integrated remote sensing and GIS technique that can be efficiently used for development and sustainable management of water resources and socio-economic activity. The outcome of the present study i.e. the waterlogged hazard and the risk map may be used by engineers, planners, decision makers and local peoples for the local development as well as the management of soil, water resources, fishing and crops land. It is also useful for future drainage projects as well as the save urbanization. Thus, the integrated remote sensing and GIS techniques can be efficiently used for the delineating of water logged zones and sustainable water resources management purposes.

Acknowledgments We greatly appreciate the tremendous support received from the Editorial board of MESE for this manuscript during its review process. The anonymous reviewer and the Executive Editor in Chief critically examined the manuscript and suggesting several valuable changes that greatly helped in bringing up the manuscript to its present shape with enhanced scientific value addition and exposition.

\section{References}

Bendimerd F (2008) State-of-the-practice in urban disaster risk management. EMI Megacities project. http://www.emi-megaci ties.org. Accessed 12 Sep 2008

Bhakar R (2011) Recent advances in geo-informatics based assessment of waterlogging and salinization hazards: a review of studies of the irrigated tracts in desert environments, Oikoassay, vol 24, http://www.jnu.ac.in/SSS/CSSP/Rajesh1.pdf. Accessed 30 Dec 2013

Blaikie P, Cannon T, Davis I, Wisner B (2005) At risk. Natural hazards, people's vulnerability and disasters, Routledge

Bonham-Carter GF (1994) Geographic information systems for geoscientists: modelling with GIS. Pergamon, Oxford 398 pp

Bowonder B, Ramana KV, Rajagopal R (1986) Water logging in irrigation projects. Sadhana 9(3):177-190

Burrough PA, McDonnell RA (1998) Principles of geographical information systems. Oxford University Press, Oxford 333 pp

Chen SP, Wang RY (2014) Analyzing hazard potential of typhoon damage by applying grey analytic hierarchy process. Water 6:1545

Choubey VK (1998) Assessment of waterlogging in Sriram Sagar command area, India, by remote sensing. Water Resour Manag 12(5):343-357

Chowdary VM, Chandran RV, Neeti N, Bothale RV, Srivastava YK, Ingle P, Singh R (2008) Assessment of surface and sub-surface waterlogged areas in irrigation command areas of Bihar state using remote sensing and GIS. Agric Water Manag 95(7):754-766

Crist EP, Cicone RC (1984) A physically-based transformation of thematic mapper data-the TM tasseled cap. IEEE Trans Geosci Remote Sens 3:256-263

Cutter SL, Boruff BJ, Shirley WL (2003) Social vulnerability to environmental hazards. Soc Sci Q 84(2):242-261

Cutter, SL, Emrich CT, Webb JJ, Morath D (2009) Social vulnerability to climate variability hazards: a review of the literature. Final report to Oxfam America. Accessed 28 Nov 2013

Dewan AM (2013) Floods in a megacity: geospatial techniques in assessing hazards, risk and vulnerability. Springer, Dordrecht

DMB (2007) Disaster Management Bureau (DMB). http://www.dmb. gov.bd

Downing TE, Bakker K (2000) Drought discourse and vulnerability. Drought Global Assess 2:213-230 
Dwivedi RS (1994) Study of salinity and water logging in Uttar Pradesh (India) using remote sensing data. Land Degrad Dev 5(3):191-199

Dwivedi RS, Sreenivas K (2002) The vegetation and water logging dynamics as derived from space borne multispectral and multitemporal data. Int J Remote Sens 23(14):2729-2740

Esri (2003) ArcGIS geostatistical analyst documentation

Gao BC (1996) NDWI-a normalized difference water index for remote sensing of vegetation liquid water from space. Remote Sens Environ 58(3):257-266

Hailin Z, Yi J, Xuesong Z, Gaoliao J, Yi Y, Baoyin H (2009) GISbased risk assessment for regional flood disaster. In: International conference on environmental science and information application technology, 2009, ESIAT 2009, vol 2. IEEE, New York, pp 564-567

Hapuarachchi HAP, Wang QJ, Pagano TC (2011) A review of advances in flash flood forecasting. Hydrol Process 25:2771-2784

Hossain S (2008) Rapid urban growth and poverty in Dhaka City. Bangladesh e-J Sociol 5:1-24

Huang D, Liu C, Fang H, Peng S (2008) Assessment of waterlogging risk in Lixiahe region of Jiangsu Province based on AVHRR and MODIS image. Chin Geogr Sci 18(2):178-183

Huang J, Chen D, Cosh MH (2009) Sub-pixel reflectance unmixing in estimating vegetation water content and dry biomass of corn and soybeans cropland using normalized difference water index (NDWI) from satellites. Int J Remote Sens 30(8):2075-2104

Ikeda K (1995) Gender differences in human loss and vulnerability in natural disasters: a case study from Bangladesh. Indian J Gender Stud 2(2):171-193

Isaaks EH, Srivastava RM (1989) An introduction to applied geostatistics. Oxford University Press, Oxford

Islam N, Sultana N (2006) The status of women in Bangladesh: is the situation really encouraging. Res J Soc Sci 1(1):56-65

Jackson RD, Huete AR (1991) Interpreting vegetation indices. Prevent Vet Med 11(3):185-200

Jensen JR (1996) Introductory digital image processing - a remote sensing perspective, 2nd edn. Prentice Hall, Upper Saddle River

Kaiser MF, El Rayes A, Ghodeif K, Geriesh B (2013) GIS data integration to manage waterlogging problem on the eastern Nile delta of Egypt

Kajimoto M, Susaki J (2013) Urban density estimation from polarimetric SAR images based on a POA correction method. IEEE J Sel Top Appl Earth Obs Remote Sens 6(3):1418-1429

Kasperson RE (1986) Six propositions on public participation and their relevance for risk communication. Risk Anal 6(3):275-281

Kates RW (1985) The interaction of climate and society. Clim Impact Assess 27:3-36

Kienberger S (2012) Spatial modelling of social and economic vulnerability to floods at the district level of Buzi, Mozambique. Nat Hazards 64(3):2001-2019

Lu Y, Carter L, Showalter PS (2010) Wildfire risk analysis at the wildland urban interface in Travis County, Texas. In: Geospatial techniques in urban hazard and disaster analysis. Springer, The Netherlands, pp 203-227

Maantay J, Maroko A, Culp G (2010) Using geographic information science to estimate vulnerable urban populations for flood hazard and risk assessment in New York City. In: Geospatial techniques in urban hazard and disaster analysis. Springer, The Netherlands, pp 71-97

Malczewski J (2000) On the use of weighted linear combination method in GIS: common and best practice approaches. Trans GIS 4:5-22

Malik AI, Colmer TD, Lambers H, Setter TL, Schortemeyer M (2002) Short-term water logging has long-term effects on the growth and physiology of wheat. New Phytol 153(2):225-236
Masuya Akiko (2014) Flood vulnerability and risk assessment with spatial multi-criteria evaluation. Dhaka Megacity. Springer, The Netherlands, pp 177-202

McFeeters SK (1996) The use of the normalized difference water index (NDWI) in the delineation of open water features. Int $\mathrm{J}$ Remote Sens 17(7):1425-1432

Meentemeyer RK, Moody A (2000) Automated mapping of conformity between topographic and geological surfaces. Comput Geosci 26(7):815-829

Meyer V, Scheuer S, Haase D (2009) A multicriteria approach for flood risk mapping exemplified at the Mulde river, Germany. Nat Hazards 48(1):17-39

Min L, Hongqing Y, Yuchun X (2002) Risk assessment and regionalization of waterlogging disasters in Hubei Province. Resour Environ Yangtze Basin 11(5):476-481

Minar MH, Hossain B, Shamsuddin MD (2013) Climate change and coastal zone of Bangladesh: vulnerability, resilience and adaptability. Middle-East J Sci Res 13(1):114-120

Mitchell JK, Devine N, Jagger K (1989) A contextual model of natural hazards. Geogr Rev 79(4):391-409

Mukherjee S (1985) Floods in West Bengal: a spatial and temporal analysis. In: Mukhopadhyay SC (ed) Geographical mosaicprofessor K.G. Bagchi felicitation volume. Modern Book Agency, Kolkata, pp 262-271

Ouma YO, Tateishi R (2014) Urban flood vulnerability and risk mapping using integrated multi-parametric AHP and GIS: methodological overview and case study assessment. Water 6(6): 1515-1545

Pandey AC, Singh SK, Nathawat MS (2010) Waterlogging and flood hazards vulnerability and risk assessment in Indo Gangetic plain. Nat Hazards 55(2):273-289

Quan RS, Liu M, Lu M, Zhang LJ, Wang JJ, Xu SY (2010) Water logging risk assessment based on land use/cover change: a case study in Pudong New Area, Shanghai. Environ Earth Sci 61(6):1113-1121

Qureshi AS, McCornick PG, Qadir M, Aslam Z (2008) Managing salinity and water logging in the Indus Basin of Pakistan. Agric Water Manag 95(1):1-10

Rahman R, Haque A, Khan SA, Salehin M, Bala SK (2005) Investigation of hydrological aspects of flood-2004 with special emphasis on Dhaka City. In: Final report. Institute of Water and Flood Management, Bangladesh University of Engineering and Technology, Dhaka

Rahman M, Pressel S, Davis BR, Nwachuku C, Wright JT, Whelton PK, Wiegmann T (2005b) Renal outcomes in high-risk hypertensive patients treated with an angiotensin-converting enzyme inhibitor or a calcium channel blocker vs a diuretic: a report from the Antihypertensive and Lipid-Lowering Treatment to Prevent Heart Attack Trial (ALLHAT). Arch Intern Med 165(8):936-946

Rashed T, Weeks J (2003) Assessing vulnerability to earthquake hazards through spatial multicriteria analysis of urban areas. Int J Geogr Inf Sci 17(6):547-576

Ritzema HP, Satyanarayana TV, Raman S, Boonstra J (2008) Subsurface drainage to combat water logging and salinity in irrigated lands in India: lessons learned in farmers' fields. Agric Water Manag 95(3):179-189

Saaty TL (2000) Fundamentals of decision making and priority theory with the analytic hierarchy process. RWS Publications, Pittsburgh

Sahu AS (2014) A study on Moyna Basin water-logged areas (India) using remote sensing and GIS methods and their contemporary economic significance. Geogr J

Sanyal J, Lu XX (2006) GIS-based flood hazard mapping at different administrative scales: a case study in Gangetic West Bengal, India. Singap J Trop Geogr 27:207-220 
Sims DA, Gamon JA (2003) Estimation of vegetation water content and photosynthetic tissue area from spectral reflectance: a comparison of indices based on liquid water and chlorophyll absorption. Remote Sens Environ 84:526-537

Singh A (2011) Estimating long-term regional groundwater recharge for the evaluation of potential solution alternatives to waterlogging and salinisation. J Hydrol 406(3):245-255

Sinha R, Bapalu GV, Singh LK, Rath B (2008a) Flood risk analysis in the Kosi river basin, North Bihar using multi-parametric approach of analytical hierarchy process (AHP). J Indian Soc Remote Sens 36(4):293-307

Sinha R, Bapalu GV, Singh LK, Rath B (2008b) Flood risk analysis in the Kosi river basin, north Bihar using multi-parametric approach of analytical hierarchy process (AHP). J Indian Soc Remote Sens 36:335-349

Smith K (2013) Environmental hazards: assessing risk and reducing disaster. Routledge, London

Story M, Congalton GR (1986) Accuracy assessment: a user's perspective. Photogramm Eng Remote Sens 52:397-399

Suriya S, Mudgal BV (2012) Impact of urbanization on flooding: the Thirusoolam sub watershed-a case study. J Hydrol 412-413:210-219

Tingsanchali TA, Karim MF (2005) Flood hazard and risk analysis in the southwest region of Bangladesh. Hydrol Process 19(10):2055-2069

Tucker CJ (1979) Red and photographic infrared linear combinations for monitoring vegetation. Remote Sens Environ 8(2):127-150
Tutu A (2005) River management in Bangladesh: a people's initiative to solve water-logging. Int Inst Environ Dev (IIED) (London) 52:117-123

Vaughan M (1987) The story of an African famine: gender and famine in twentieth century Malawi. Cambridge University Press, Cambridge

Wang Y, Li Z, Tang Z, Zeng G (2011) A GIS-based spatial multicriteria approach for flood risk assessment in Dongting lake region, Hunan, Central China. Water Resour Manag 25(13):3465-3484

Wilhelmi OV, Wilhite DA (2002) Assessing vulnerability to agricultural drought: a Nebraska case study. Nat Hazards 25(1):37-58

Wilhite DA (2000) Drought as a natural hazard: concepts and definitions. Drought Global Assess 1:3-18

Willet K, Sharda R (1991) Using the analytic hierarchy process in water resource planning: selection of flood control projects. J Sociol Econ Plan Sci 25:103-112

Wilson EH, Sader SA (2002) Detection of forest harvest type using multiple dates of Landsat TM imagery. Remote Sens Environ 80(3):385-396

Zhang H, Zhang J, Han J (2005) The assessment and regionalization of flood/waterlogging disaster risk in middle and lower reaches of Liao River of Northeast China. In: Proceedings of the fifth annual IIASA-DPRI forum on integrated disaster risk management, pp 103-118 